Qiro'ah| Jurnal Pendidikan Agama Islam

Vol. 11 No. 1 2021| https://ejurnal.iiq.ac.id/index.php/qiroah P-ISSN: 2085-0115 E-ISSN: 2656-3819

DOI: https://doi.org/10.33511/qiroah.v11n1.52-75
Diterima $\quad: 12$ Mei 2021

Direvisi : 17 Mei2021

Disetujui : 03 Juni 2021

Diterbitkan : 12 Juni 2021

\title{
NILAI-NILAI TAUHID DALAM MATA PELAJARAN BIOLOGI (Telaah Mata pada Pelajaran Biologi)
}

\author{
Yudril Basith \\ Universitas Nahdlatul Ulma Indonesia \\ yudrilbasith@unusia.ac.id
}

\begin{abstract}
This study aims to find the values of tauhid (religion) in biology (science) subjects. This type of research is a qualitative study using an interpretive approach. The main source of the research is the biology textbook for SMA / MA students written by Slamet Prawirohartono. The conclusion of this research is that someone who studies biology will be able to get an understanding of monotheism (religion). This can be seen from the value of monotheism contained in the subject of biology, which is tawhid rububiyah that mean the god is the only one can control and creator universe. Someone can develop his potention to maintain and preserve the universe as a form of worship to God. Second, uluhiyah, this is in the form of the tasbih of the universe in the form of the order and balance of the universe that Allah created for every creature, three Asma 'wa sifah, this is the form of Allah's affection for every creature that He has created. This can be seen from biological materials such as material on scientific methods that recommend utilizing the five senses in studying ancient verses, biodiversity as a gift of God's beauty, ecology which is the unity and harmony of God's creation in order to maintain the balance of the environment (ecosystem)
\end{abstract}

Keyword : Education, integration science and religion, Tauhid, Biolog.

\begin{abstract}
Abstrak
Penelitian ini bertujuan untuk menemukan nilai-nilai tauhid (agama) pada mata pelajaran biologi (sains). Jenis penelitian ini bersifat kajian kualitatif dengan menggunakan pendekatan interpretatif. Sumber utama data penelitian ini adalah buku pelajaran biologi untuk siswa SMA/MA yang ditulis oleh Slamet Prawirohartono. Kesimpulan penelitian menyatakan bahwa seseorang yang belajar biologi akan mampu mendapatkan pemahaman tentang ketauhidan (agama). Hal ini bisa dilihat dari nilai tauhid yang terkandung dalam mata pelajaran biologi yakni yakni tauhid yang bersifat rububiyah, yakni meng-esa-kan Allah dengan perbuatan yaitu dengan cara memanfaatkan potensi yang ada pada manusia untuk memelihara dan melestarikan alam semesta sebagai bentuk ibadah kepada tuhan. kedua yaitu uluhiyah, ini ada pada bentuk tasbihnya alam semesta berupa keteraturan dan keseimbangan alam semesta yang diciptakan Allah kepada setiap makhluknya, ketiga Asma' wa sifat ini ada apa bentuk kasih kasih sayangnya Allah kepada setiap makhluk yang telah Dia cipatkan. Hal ini bisa dilihat dari materi-materi biologi seperti materi tentang metode ilmiah yang menganjurkan untuk memanfaatkan panca indra dalam menelaah ayat-ayat kauniyah, keanekaragaman hayati sebagai anugrah keindahan tuhan, ekologi yang merupakan keteratuan dan keserasian ciptaan tuhan dalam rangka merawat keseimbangan lingkungan (ekosistem).
\end{abstract}

Keyword : Pendidikan; Integrasi ilmu dan agama; Tauhid; Biologi. 
Qiro'ah| Jurnal Pendidikan Agama Islam

Vol. 11 No. 1 2021| https://ejurnal.iiq.ac.id/index.php/qiroah P-ISSN: 2085-0115 E-ISSN: 2656-3819

DOI: https://doi.org/10.33511/qiroah.v11n1.52-75
Diterima $\quad: 12$ Mei 2021

Direvisi : 17 Mei2021

Disetujui : 03 Juni 2021

Diterbitkan : 12 Juni 2021

\section{PENDAHULUAN}

Persoalan integrasi sains dan agama masih menjadi perdebatan. Salah satu yang masih hangat menjadi perdebatan adalah tentang konsep ketuhanan. Sains memandang bahwa Tuhan adalah bukan wilayah ilmu pengetahuan sedangkan agama memandang bahwa Tuhan adalah wilayah ilmu. ${ }^{1}$

Konsepsi ketuhanan dianggap tidak relevan lagi oleh Karl Marx karena itu tidak ada makna. Ide tentang Tuhan tidak berguna lagi bagi kemanusiaan, sebab kepercayaan kepada Tuhan itu merupakan desahan makhluk yang tertekan alias candu. Karl Marx menjauhkan konsep ketuhanan dari konsepsi ilmu. ${ }^{2}$ Ada dua alasan menurut Griffin mengapa pengkajian tentang ketuhanan pada abad modern dikesampingakan dari wilayah kajian ilmu pengetahuan. Pertama Tuhan adalah nilai-nilai trasenden, dan jiwa manusia yang merupakan inti dari visi religius yang berdasarkan tradisi kitab suci tidak lagi memiliki peranan dalam semesta "pandangan kaum Modern". ${ }^{3}$ Kedua, teologi dianggap tidak relevan lagi, sebab modernitas sudah bisa menggantikan teologi. Teologi yang merupakan sikap dan pertahanan diri orang beriman untuk mencapai keselamatan sudah tergantikan oleh pandangan liberal modern berbasis keilmuan. Keselamatan dianggap bisa diperoleh melalui kemajuan materi, yang dimungkinkan oleh pasar, teknologi, ilmu ekonomi, ilmu alam, serta dukungan filsafat ilmu yang merupakan dua cabang pengganti teologi pada zaman modern ${ }^{4}$

Disisi lain teologi posmodern pada saat ini berusaha menempatkan eksistensi "Tuhan" dalam teologi klasik yang dipandang anti-science agar lebih diterima oleh dunia modern yang dinilai ateistik-naturalistik. Dunia modern tidak menerima peran Tuhan yang absolut dalam kehidupan mereka. Sikap tersebut didasarkan kepada banyaknya perilakuperilaku jelek serta distortif yang justru pada dark ages dilakukan oleh tokoh-tokoh agama. Hal lain yang juga dianggap sebagai masalah serius adalah tentang keadilan Tuhan dan ketidakbebasan manusia, ditambah dengan adanya revolusi industri dan perkembangan sains yang berujung pada penolakan mereka pada Tuhan. ${ }^{5}$

Pandangan tersebut dinilai oleh Syed Muhammad Nuqaib Al Attas adalah pandangan yang keliru, sebab mereka memandang kebenaran dan realitas bukan berdasarkan kepada ilmu wahyu dan dasar-dasar keyakinan agama tetapi berdasarkan kepada tradisi kebudayaan yang diperkuat oleh dasar-dasar filosofis positivistik, tidak menghubungkan dengan sesuatu yang hakiki (tauhid), manusia hanya sebagai diri jasmani dan hewan rasional. ${ }^{6}$

Senada dengan al Attas, Nurcholish Majid menyatakan bahwa konsep mengenai "Tuhan" di abad modern ini dianggap tidak lagi diperlukan untuk menjawab pertanyaan tentang mengapa manusia hidup, dan bagaimana manusia menempuh hidup sehari-hari.

${ }^{1}$ Samsul Hidayat, "Sacred Science vs. Secular Science: Carut Marut Hubungan Agama dan Sains", Kalam: Jurnal Studi Agama dan Pemikiran Islam Volume 8, Nomor 1, Juni 2014, 89.

${ }^{2}$ Karen Armstrong, Sejarah Tuhan(Bandung: Mizan, 2004),456.

${ }^{3}$ Bambang Sugiharto, "Kata Pengantar" dalam David Ray Griffin, Tuhan dan Agama dalam Dunia Postmodern, (Bandung : 2005.),11.

${ }^{4}$ David Ray Griffin, Tuhan dan Agama dalam Dunia Postmodern, (Bandung : 2005.), 15-16.

${ }^{5}$ Atho'illah Umar, "Teologi Posmodern: Menimbang Konsep Naturalisme-Teistik" Teosofi (Volume 2 Nomor 1 Juni 2012), 95.

${ }^{6}$ Syed Muhammad Naquib Al Attas, Islam dan Sekularisme (Bandung : Institut Pemikiran Islam dan Pembangunan Insan, 2011), 172-182. 
Qiro'ah| Jurnal Pendidikan Agama Islam

Vol. 11 No. 1 2021| https://ejurnal.iiq.ac.id/index.php/qiroah P-ISSN: 2085-0115 E-ISSN: 2656-3819

DOI: https://doi.org/10.33511/qiroah.v11n1.52-75
Diterima $\quad: 12$ Mei 2021

Direvisi : 17 Mei2021

Disetujui : 03 Juni 2021

Diterbitkan : 12 Juni 2021

Sebab semuanya dapat dijelaskan dengan ilmu pengetahuan. Inilah sebabnya mengapa Nurcholish Majid menginkan bahwa bagaimana menghadirkan kembali peran Tuhan di dunia Modern. ${ }^{7}$

Sains dan agama sering dipandang tidak akur. Asumsinya adalah sains hanya menjelaskan hal-hal yang emperis. Sains mepertimbangkan apa yang disebut dengan kebenaran secara ilmiah. Sedangkan wilayah moral (agama) dan keindahan bukan kajian ilmu pengetahuan. ${ }^{8}$ Betrand Russell mengatakan bahwa otoritas sains yang dipandang sebagai epos modern, memandang otoritas agama sudah tidak menjadi tolak ukur untuk suatu kebenaran. Sains tidak membangun konsep moralitas dan harapan manusia. Otoritas sains hanya mengungkap segala sesuatu yang dipastikan kebenarannya secara ilmiah. ${ }^{9}$

Pemisahan antara agama dengan ilmu bisa melahirkan manusia yang tidak seimbang, dimana mereka akan saling berebut dominasi, disamping itu pemisahan ini juga yang akan menyebabkan aspek kerohanian dengan sendirinya dikesampingkan sehingga menyebabkan wujudnya keterbatasan dalam sumber ilmu. Asumsi-asumsi tersebut menjadikan Ismail Raji Alfaruqi menganggap ilmu pengetahuan harus berlandaskan sesuatu yang apriori yakni konsep ketuhanan (tauhidic) ${ }^{10}$ dan tidak kepada sesuatu yang relatif untuk memastikan kewujudan ilmu itu selaras dengan keyakinan yang mutlak dan tidak bersifat sementara. ${ }^{11}$

Sebenarnya titik temu antara tauhid dan sains itu bisa sejalan dalam pengembangan ilmu pengetahuan yakni dengan cara memberikan berbagai ekpresi atau ungkapan bermakna dalam teori maupun praktek, hal ini bisa dilakukan dengan cara. Pertama prinsip kesatuan kosmis, khususnya kesatuan dunia alam. Kedua prinsip kesatuan agama dan sains. Para saintis-filosof muslim menjadikan dua konsekuensi tersebut sebagai pondasi maupun tujuan sains. Melalui pembuktian adanya kesaling-berkaitan seluruh bagian dari alam semesta yang diketahui, mereka pun semakin yakin bahwa kesatuan kosmis membuktikan dengan jelas keesa-an Allah. ${ }^{12}$ Konsep tauhid inilah yang memberikan identitas pada peradaban Islam, yang mengikat semua unsurnya bersama-sama dan menjadikan unsur-unsur tersebut sebagai suatu kesatuan integral dan organis. ${ }^{13}$

\footnotetext{
${ }^{7}$ Nurcholish Majid, Islam Agama Peradaban: Membangun Makna dan Relevansi Doktrin Islam Dalam sejarah, (Jakartat : Penerbit Paramadina, 1995), 146.

${ }^{8}$ Edward Teller, "Science and Morality": American Association for the Advancement of Science Vol. 280, No. 5367 May 22, 1998), 1200-1201 http://www.jstor.org/stable/2896053 (dikases 21 Januari 2015)

${ }^{9}$ Kebenaran ilmiah yakni sesuatu yang yang emperik dan bisa di verifikasi. Lihat Betrand Russel, Sejarah Filsafat Barat dan Kaitannya Dengan Kondisi Sosio-Politik Zaman Kuno Hingga Sekarang (Yogyakarta : Pustaka Pelajar, 2007), 645-647.

${ }^{10}$ Umma Farida, "Pemikiran Ismail Raji Al-Faruqi Tentang Tauhid, Sains, dan Seni" Fikrah, (Vol. 2, No. 2, Desember 2014), 210.

${ }^{11}$ Zuraidah bt Othman, Aizan Ali dan Mat Zin "Pendidikan Integratif Dalam Islam : Kesepaduan Iman, Ilmu dan Amal (Integrative Education In Islam : Unity Faith, Knowledge And Charity)

${ }^{12}$ Osman Bakar, Tauhid dan Sains : Perspektif Islam tentang Agama \& Sains, judul asli Tawhid and Scince : Islamic Perspective on Religion and Science. (Bandung : Pustaka Hidayah, 200), 30.

${ }^{13}$ Umma Farida, "Pemikiran Ismail Raji Al-Faruqi Tentang Tauhid, Sains, dan Seni" Fikrah, (Vol. 2, No. 2, Desember 2014). 210.
} 
Qiro'ah| Jurnal Pendidikan Agama Islam

Vol. 11 No. 1 2021| https://ejurnal.iiq.ac.id/index.php/qiroah P-ISSN: 2085-0115 E-ISSN: 2656-3819

DOI: https://doi.org/10.33511/qiroah.v11n1.52-75
Diterima $\quad: 12$ Mei 2021

Direvisi $\quad: 17$ Mei2021

Disetujui : 03 Juni 2021

Diterbitkan : 12 Juni 2021

Munculnya doktrin (tauhid) sebagai awal dan akhir dari tujuan ilmu pengetahuan harusnya menjadi benang merah untuk menjembantani antara agama dan sains. Tauhid pada umumnya dibagi menjadi 3 kalisifikasi, Pertama, Tauhid Rububiyah, yaitu tauhid mengesakan Allah dengan perbuatan-Nya, seperti keyakinan hanya Allah yang menciptakan dan memelihara langit dan bumi, yang memberi rizqi, yang menghidupkan dan mematikan. Kedua, Tauhid Uluhiyah, mengarahkan seorang muslim untuk hanya menyembah kepada Allah saja dan tidak menyembah selainnya, atau mengesakan Allah dengan perbuatan para hamba berdasarkan niat taqarrub yang diisayaratkan seperti doa, nadzar, kurban, raja', tawakkal, taqwa, ibadah dan inabah, Ketiga, Tauhid asma' wa sifat, yaitu tauhid yang menetapkan apa yang telah ditetapkan oleh Allah dan Rasul-Nya berupa nama-nama yang baik, dan memliki sifat kesempurnaan. ${ }^{14}$

Menurut Osman Bakar konsep pengembangan ilmu pengetahuan harus berbasis tauhid. Dimana doktrin tauhid mengenai metafisika Keesaan Allah yang terkandung dalam pertama kalimat syahadat yakni "tidak ada tuhan selain Allah" yang merupakan inti agama adalah penerimaan doktrin dan pengamalan nyata tauhid dalam semua domain kehidupan termasuk ilmu pengetahuan. ${ }^{15}$ Begitu pula menurut Karwadi, ${ }^{16}$ titik temu antara sains dan agama terletak tatanan filosofis, yang hal ini bisa dilihat dari nilai fundamental dari sains dan agama yang mempunya tujuan yang sama yang mencari kebanaran.

Untuk mencapai konsep tauhid yang tidak lepas dari sains atau dengan bahasa lainnya integrasi ilmu dan agama, maka disinilah pentingnya peneletian ini, dimana titik temunya adalah berusaha mencari dan menemukan nilai-nilai tauhid dalam matapelajaran biologi, yang mana biologi merupakan salah satu cabang dari pada sains ilmu kealaman (sains) yang berbicara tentang makhluk hidup, berbicara tentang manusia, berbicara tentang lingkungan, berbicara tentang tumbuhan. biologi merupakan ilmu yang mempelajari tentang ilmu kehidupan, didalam kehidupan banyak terdapat pembelajaran tentang nilai-nilai ketuhanan.

Objek penelitian ini akan berupaya menelaah nilai-nilai tauhid (agama) dalam sains pada mata pelajaran biologi sebab didalam materi pelajaran biologi terdapat nilia-nilai tauhid yang menjelaskan tentang eksistensi ketuhanan. Jenis penelitian ini bersifat kajian kulaitatif (kepustakaan) dengan menggunakan pendekatan interpretatif. Sumber utama data penelitian ini adalah buku pelajaran biologi untuk siswa SMA/MA yang ditulis oleh Slamet Prawirohartono, penerbit Bailmu, kurikulum 2013. Pemilihan buku ini juga dilandaskan falsafah pendidikan Nasional. Dalam lingkup tataran normatif yakni berketuhanan Yang Maha Esa dan kemudian di jabarkan dalam UUD 1945. Kemudian di perinci lagi dalam tujuan pendidikan Nasional yaitu membentuk peserta didik untuk bertaqwa kepada tuhan

\footnotetext{
${ }^{14}$ Ayi Darmana, "Internalisasi Nilai Tauhid dalam Pembelajaran Sains” Vol. XVII No. 1 $2012 / 1433,71$.

${ }^{15}$ Osman Bakar, Tauhid dan Sains : Perspektif islam tentang Agama \& Sains, 2008 judul Aslim Tawhid and Scince : Islamic Perspective on Religion and Science. Bandung : Pustaka Hidayah,

${ }^{16}$ Karwadi, "Integrasi Paradigma Sains dan Agama dalam Pembelajaran Aqidah (Ketuhanan) (Telaah Tcoritis Dari Perspektif Kurikulum Integratif)" Jurnal Penelitian Agama, VOL. XVII, NO. 3September-Desember 2008.
} 
Qiro'ah| Jurnal Pendidikan Agama Islam

Vol. 11 No. 1 2021| https://ejurnal.iiq.ac.id/index.php/qiroah P-ISSN: 2085-0115 E-ISSN: 2656-3819

DOI: https://doi.org/10.33511/qiroah.v11n1.52-75
Diterima : 12 Mei 2021

Direvisi : 17 Mei2021

Disetujui : 03 Juni 2021

Diterbitkan : 12 Juni 2021

yang maha Esa. ${ }^{17}$ Kemudian melihat dari tujuan dari pada pembelajaran IPA yakni pendidikan IPA memiliki tujuan utama untuk menanamkan keyakinan terhadap Tuhan Yang Maha Esa berdasarkan keberadaan, keindahan dan keteraturan alam ciptaan-Nya. Sehingga dipandang perlu untuk menelaah buku mata pelajaran untuk menguak nilai-nilai tauhid yang terkandung didalamnya.

\section{HASIL DAN PEMBAHASAN}

\section{Dikotomi dan Integrasi Ilmu dan Agama}

\section{a. Dikotomi Agama dan Sains}

Sains dan agama seringkali dipandang bermusuhan. Sains dipandang menelusuri hubungan sebab akibat antarperistiwa, sedangkan agama mencari makna dan tujuan hidup. Keduanya dipandang tidak saling berkaitan. Keduanya berjalan sendiri-sendiri, terpisah dan tidak hubungan-konflik. ${ }^{18}$.

Latar belakang ketegangan sains dan agama berawal dari cara pandang keduanya memandang objek yang dikaji. Hal ini bermula karena ilmuan dan agamawan mendekati pertanyaan perihal eksistensi dari titik berangkat yang berbeda antara keduanya. Sains melakukan pendekatan dengan observasi dan eksperimen, sedangkan agama dibangun berdasarkan wahyu. Pertentangan itu semakin keras ketika ilmuan menganggap diri rasional dan memandang kaum agamawan sebagai wakil dari sikap dan pandangan yang tidak rasional. ${ }^{19}$

Ketegangan sains dan agama itu kira-kira muncul pada abad ke-17 tentang penemuan yang dilakukan oleh ilmuan Galileo Galilei yang mendukung teori bumi mengitari matahari yang ditentang Paus Gereja Vatikan yang memahami kosmos berdasarkan penafsiran literal kitab suci. ${ }^{20}$ Kemudian dilanjutkan dengan para tokoh seperti Agus Comte, Darwin, Freud, dan sebagainya.

Ken Wilber menyebutkan bahwa ketegangan sains dan agama ini seperti antara pikiran dan tubuh, kesadaran dan materi, fakta dan nilai yang selalu menjadi duri dalam daging bagi sebagian besar para filusuf, kemudian orang yang awam tanpa beban memihak salah satu antara keduanya, antara ilmu pengetahuan (serangkaian pengetahuan teknis empiris) dengan agama (atau serangkaian makna, nilai, tujuan trasendental, dan kehadiran imanen. $^{21}$

${ }^{17}$ Abdul Majid, "Pendidikan Berbasis Ketuhanan : Mereposisi Pendidikan Agama Islam Untuk Mewujudkan Tujuan Pendidikan Nasional. Pidato pengukuhan jabatan guru besar ilmu pengkajian islanm pada jurusan mata kuliah fakultas pendidikan ilmu social Universitas Pendidikan Indonesia Rabu, 21 November 2017 hal. 5

${ }^{18}$ Ian G. Barbour, Juru Bicara Tuhan antara Sains dan Agama, (Bandung : Mizan, 2004), 13.

${ }^{19}$ Samsul Hidayat, "Sacred Science vs. Secular Science:Carut Marut Hubungan Agama dan Sains", Kalam: Jurnal Studi Agama dan Pemikiran Islam Volume 8, Nomor 1, Juni 2014, 89.

${ }^{20}$ Samsul Hidayat, "Sacred Science vs. Secular Science:Carut Marut Hubungan Agama dan Sains", Kalam: Jurnal Studi Agama dan Pemikiran Islam Volume 8, Nomor 1, Juni 2014, 88.

${ }^{21}$ Ken Wilber, A Theory of everything : Solusi Menyeluruh atas Masalah Masalah Kemanusiaan, (Bandung : Mizan, 2012), 125. dengan judul Asli A Theory Of Everything, An Integral Vison For Business, Politics, Science, And Spirituality. 
Qiro'ah| Jurnal Pendidikan Agama Islam

Vol. 11 No. 1 2021| https://ejurnal.iiq.ac.id/index.php/qiroah P-ISSN: 2085-0115 E-ISSN: 2656-3819

DOI: https://doi.org/10.33511/qiroah.v11n1.52-75

$\begin{array}{ll}\text { Diterima } & : \text { 12 Mei } 2021 \\ \text { Direvisi } & : 17 \text { Mei2021 } \\ \text { Disetujui } & : \text { 03 Juni } 2021 \\ \text { Diterbitkan } & : \text { 12 Juni } 2021\end{array}$

Mari kita perinci lagi dari kajian filsafat ilmu ketegangan antara sains dan agama. Dari sisi ontologis sains modern memandang yang ada (being) sebagai objek kajian dalam sains, dalam konteksnya sains hanya membatasi diri pada objek-objek empiris, fisik, materi dan eksternal. Sedangkan agama tidak hanya membatasi pada objek-objek fisik, tetapi juga yang bersifat metafisik, hidup setelah mati. Dengan kata lain sains modern hanya berurusan dengan objek-objek yang teramati oleh indra. Oleh karena itu berdasarkan perspektif positivisme tersebut sifat utama sains modern adalah berorentasi pada fenomena empiris.

Dari sudut epistimologi, sains membangun kerangka epstimologinya yaitu bagaimana seseorang dapat memperoleh suatu pengetahuan yang benar dengan hanya membenarkan dengan kerangka metode ilmiah, dengan melibat proses verifikasi dan pengakuan secara sistematis, verbal dan empirisnya. Mereka memandang metode ilmiah dalam pengertiannya yang postivistik itu sebagai satu-satunya jalan untuk mengetahui atau memperoleh ilmu pengetahuan, menolak wahyu sebagai sumber ilmu pengatahuan. Sedangkan agama masih mempercayai wahyu dan pengalaman spiritual sebagai sumber kebenaran. Dari sudut aksiologi sains barat mengkalim bahwa ilmu bersifat bebas nilai (value free), sehingga kaum akademisi barat mempertahankan ide "sains untuk sains". mereka menolak dan mengabaikan nilai-nilai moral dan menganggapnya sebagai relatif, subjektif dan personal, sedangkan agama memandang ilmu sarat akan nilai. Pada initinya sains barat bertujuan untuk memuaskan kebutuhan materi yang bersifat duniawi dengan mengabaikan pemenuhan kebutuhan rohani, moral dan spiritual. Sedangkan agama masih beranggapan bahwa ilmu masih mempunyai terkatan sama yang Ilahi. ${ }^{22}$

Filsuf Prancis Auguste Comte (1798-1857), sebagaimana dikutip oleh al-Qarâdawî, mengatakan bahwa peran agama akan berakhir seiring dengan kemajuan sains. Pernyataan ini terus dikampanyekan oleh para pendukungnya dalam tulisan-tulisan mereka. Mereka berkata bahwa masa gaib telah berlalu, digantikan oleh sains. Semua permasalahan yang tidak bisa dibuktikan di laboratorium telah jatuh nilainya. Ia juga mengatakan agama hanya cocok untuk masyarakat yang masih primitif dan terbelakang. menurut Comte, sekarang adalah era positivisme, di mana semua kajian dapat divalidasi secara rasional dan dibuktikan secara emperik. ${ }^{23}$

Kerangka berfikir tersebut memang mampu mambawa barat kepada kemajuan ilmu pengetahuan yang sangat pesat. Hal ini tak dapat dipungkiri lagi dilihat dari kemajuan peradaban yang ada pada eropa dan amerika saat ini. Namun kehawatiran mulai muncul akibat kemjuan sains yang positivistik tersebut sudah mulai menimbulkan beberapa masalah mulai dari krisis moral dan krisis spiritual hingga kirisis lingkungan. ${ }^{24}$

Kemudian pada abad ke-20, penyaksian terhadap wilayah ilmu mulai berubah, khususnya berkat relativitas Einsten, teori kuantum dan kosmologi. Sejak saat itu, perubahan dalam memandang ruang, waktu, rasionalitas, kebenaran dan ilmu-ilmu itu berubah tak bisa

\footnotetext{
${ }^{22}$ M. Hadi Masruri dan Imron Rossidy, Filsafat Sains dalam Al qur'an : Melacak Kerangka Dasar Integrasi Ilmu dan Agama (Malang : UIN-Malang Press, 2007),2-5.

${ }^{23}$ Moh. Jufriyadi Sholeh, "Pandangan dan Kritik yusuf al-Qardawi terhadap Pandangan Barat tentang Agama dan Ilmu Pengetahuan". Marâji': Jurnal Studi Keislaman Volume 2, Nomor 1, September 2015, 92-93

${ }^{24}$ M. Hadi Masruri dan Imron Rossidy, Filsafat Sains dalam Al qur'an : Melacak Kerangka Dasar Integrasi Ilmu dan Agama ( Malang : UIN-Malang Press, 2007), 2.
} 
Qiro'ah| Jurnal Pendidikan Agama Islam

Vol. 11 No. 1 2021| https://ejurnal.iiq.ac.id/index.php/qiroah P-ISSN: 2085-0115 E-ISSN: 2656-3819

DOI: https://doi.org/10.33511/qiroah.v11n1.52-75
Diterima : 12 Mei 2021

Direvisi : 17 Mei2021

Disetujui : 03 Juni 2021

Diterbitkan : 12 Juni 2021

di katakan kebenaran yang pasti, pada abad ke 20 ilmu terpaksa menyadari kerapuhan segala batas yang sempat diyakininya. Lantas bergerak kearah dimensi kepercayaan dan etika. Disadari dengan kemungkinan yang tidak pasti tersebut maka tentang realitas memang bisa dihampiri dengan berbagai cara, dan berbagai cara tersebut tidak harus menafikan satu sama lain. Namun bisa saling melengkapi dan mengoreksi serta memperkaya. ${ }^{25}$

\section{b. Integrasi Agama dan Sains}

Ketegangan sains dan agama secara tidak langsung telah membuat dikotomi antara sains dan agama, biasnya dalam islam adalah munculnya klasifikasi ilmu, yakni mana yang wajib dan mana yang tak wajib untuk dipelajari. Klasifikasi ilmu tersebut secara tidak sadar telah mengakar dalam pemikiran umat muslim itu sendiri.

Menurut Mulyadi kertanegara dikotomi ilmu dan agama tersebut sangat potensial muncul dari klasifikasi ilmu yakni antara ilmu-ilmu agama dan ilmu ilmu umum. Klasifikasi tersebut mengarahkan umat muslim untuk lebih mementingkan ilmu agama dibanding dengan ilmu umum. Penekanan yang begitu besar terhadap ilmu -ilmu agama yang diberikan pemuka agama terutama bagi kalangan islam telah mengakibatkan ketertinggalan dalam bidang ilmu pengetahuan. Klasfikasi ilmu tersebut menurut Mulyadi dipengaruhi oleh gagasan imam al Gazali yang memandang ada dua katagori ilmu yakni ilmu sebagai fardu ain dan fardu kifayah, fardu ain untuk ilmu-ilmu agama, dan fardu kifayah untuk ilmu-ilmu umum. ${ }^{26}$

Disisi lain bias dari klasifikasi ilmu tersebut menjadikan umat muslim menganggap ilmu-ilmu agama adalah ilmu yang paling pas untuk di kembangkan karena ilmu agama adalah ilmu langit yang akan menjadikan manusia sholeh. Ilmu agama dianggap ilmu yang paling cepat menuju tuhan. Meminjam bahasanya Azyumardi Azra bahwa ilmu-ilmu agama dianggap "jalan tol" menuju tuhan ${ }^{27}$. Sedangkan ilmu-ilmu umum adalah ilmu yang bernuansa duniawi ilmu masih termarginalkan. Motivasi kesalehan mendorong para muslim pada saat itu bergerak dalam lapangan ilmu-ilmu agama dibanding ilmu-ilmu umum yang tidak terkait dengan dengan soal pahala. Hal ini disinyalir juga karena adanya kepentingan politik tertentu untuk melanggengkan kekuasaan.

Klasifikasi ilmu tersebut juga berujung kepada dikotomi pendidikan teruntuk konteks indonesia. Hal ini bisa dilihat dari dualisme penyelenggaraan pendidikan, yakni Diknas dan Depag. ${ }^{28}$ Harun Nasition menyebutnya sains yang berasal dari eropa, yang dibawa bukan dari orang-orang islam dianggap bukan merupakan hasil dari ulama yang dibawa oleh orang-orang Islam. Oleh karenanya ditentang oleh ulama-ulama Islam. Dengan demikian kesenjangan agama dan sains telah berdampak pada dulaisme tersebut dalam

${ }^{25}$ Zainal Abidin Bagir ed. Et. All, Integrasi Ilmu dan Agama : Interpretasi dan Aksi, (Bandung : Mizan, 2005), 40.

${ }^{26}$ Mulyadi Kertanegara, Integrasi Ilmu : Sebuah Rekonstruksi Holistik, (Bandung, Arasy Mizan Pustaka, 2005),27.

${ }^{27}$ Azyumardi Azra, Pendidikan Islam : Tradisi Menuju Milenium Baru (Jakarta : Perebit Kalimah, 2001),ix.

${ }^{28}$ Imam Suprayogo, Pendidikan Berparadigma Al-Qur'an : Pergulatan Membangun Tradisi dan Aksi Pendidikan, (Malang: UIN Press Malang, 2004),15. 
Qiro'ah| Jurnal Pendidikan Agama Islam

Vol. 11 No. 1 2021| https://ejurnal.iiq.ac.id/index.php/qiroah P-ISSN: 2085-0115 E-ISSN: 2656-3819

DOI: https://doi.org/10.33511/qiroah.v11n1.52-75
Diterima $\quad: 12$ Mei 2021

Direvisi : 17 Mei2021

Disetujui : 03 Juni 2021

Diterbitkan : 12 Juni 2021

pendidikan dunia islam zaman modern. Pendidikan Islam berjalan di madrasah-madrasah sedangkan sains berjalan di sekolah-sekolah. ${ }^{29}$

Munculnya ide integrasi ilmu dan agama ini merupakan salah satu usaha untuk memadukan ilmu dan agama. Integrasi ini pertama kali didengungkan oleh Barbaur, dengan melihat fenomena tentang pencarian kebenaran. Dalam kerangka integrasi agama dan sains, dijelaskan bahwa teori-teori sains adalah salah satu sumber konsepsi terbaik tentang alam yaitu Theology of nature, kemudian kitab suci atau doktrin-doktrin agama sama-sama dianggap valid menjadi sumber bagi suatu pandangan dunia yang koheren bagi kaum beriman. Doktrin-doktrin agama/kitab suci ataupun teori-teori sains dianggap sebagai "bahan mentah" yang melalui proses penafsiran dikembangkan menjadi metafisika atau pandangan dunia yang koheren. ${ }^{30}$

Ian Barbour membagi pemetaan mengenai sains dan agama menjadi empat tipe. Pertama, konflik, tipe ini menjelaskan bahwa pertentangan antara sains dan agama mencakup materialisme ilmiah dan litaralisme al-Kitab. Penganut materialisme mengklaim bahwa dunia terdiri dari materi semata, tidak ada ruang bagi jiwa, roh atau Allah. Dan mengklaim bahwa sains adalah satu-satunya jalan untuk memperoleh pengetahuan yang sebenarnya. Sedangkan literalisme al-Kitab percaya bahwa al-Kitab harus dibaca secara harfiah tanpa penafsiran. Karena al kitab itu memberikan pengetahuan yang benar tentang dunia, kemanausiaan, dan Allah. Kedua, Kemandirian. Sains dan agama memiliki metode dan bahasa masing masing yang berbeda. Keduanya mencari kebenaran sesuai dengan metodenya masing-masing tanpa bersinggungan. Jadi tidak ada konflik, juga tak ada kompromi ataupun interaksi. Ketiga Dialog. tipe ini berusaha untuk mendialogkan antara agama dan sains mencakup pertanyaan-pertanyaan seputar batas dan kesejajaran metodologi. Walaupun sains mengungkapkan kepada kita banyak hal tentang dunia. Sehingga beberapa pertanyaan yang terletak di ujung atas batas sains, tentang pertanyaan yang di timbulkan sains, tetapi ia tidak pernah mampu menjawabnya. Apabila alam memiliki awal apa terjadi sebelum itu ?. Olehkarena itu kedua cendekiawan sains dan agama berkompromi dan berdialog untuk menjawab pertanyaan tersebut, keduanya mengunakan data (fakta-fakta emepris untuk sains; kitab suci, pengalaman religious untuk agama). Keempat, Integrasi. Tipe ini mencakup teologi natural tentang alam dan sintesis sistematis. Teologi natual adalah upaya untuk mulai dengan dunia dan menemukan sesuatu tentang Allah, bahwa Allah ada, Hakikat Allah, kehendak Allah dan maksudnya. Suatu teologi natural mulai dengan teologi dan berupaya menggabungkan kedalam penemuan sains. teologi natural melibatkan perumusan ulang teologi daru sudut penemuan. Tujuan sintesis sistematis adalah penggabungan teologi dan sains dalam satu kerangka tunggal yang menggunakan metafisika tunggal. Seperti filsafat Alferd North Whitehead atau metafisika Thomistik. Sehingga dengan cara ini konsep sepeti ruang, waktu, kausalitas, pikiran, roh, bahkan Allah digunakan dengan cara serupa baik dalam teori dan penelitian teologis. ${ }^{31}$

Kemudian ada Ken Wilber berbicara tentang integrasi ilmu pengetahuan (sains) dan agama dalam buku The Teory of Everything di tulis secara singkat mengapa harus ada

\footnotetext{
${ }^{29}$ Harun Nasution, Islam Rasional : gagasan dan pemikiran ( Bandung : mizan, 1995), 40-41

${ }^{30}$ Ian G. Barbour, Juru Bicara Tuhan antara sains dan agama, (Bandung : Mizan, 2004), 27.

${ }^{31}$ Ted Peters dan Gaymon Bennett, Menjembatani Sains dan Agama.(Gunung Mulia : Jakarta, 2006),23-25.
} 
Qiro'ah| Jurnal Pendidikan Agama Islam

Vol. 11 No. 1 2021| https://ejurnal.iiq.ac.id/index.php/qiroah P-ISSN: 2085-0115 E-ISSN: 2656-3819

DOI: https://doi.org/10.33511/qiroah.v11n1.52-75
Diterima $\quad: 12$ Mei 2021

Direvisi : 17 Mei2021

Disetujui : 03 Juni 2021

Diterbitkan : 12 Juni 2021

integrasi ilmu pengetahuan dan agama, 1). Ilmu pengetahuan menolak agama. Ironi masih menjadi sikap umum para ilmuan masa kini yang secara agresif diwakili oleh Richard Dawkins, Francis Crick, dan Steven Pinker, bagi mereka agama adalah relik kepercayaan masa lampau, tidak lebih tidak kurang atau paling banter sebuah tipu muslihat kelangsungan hidup bagaimana alam menghasilkan spesies. 2) Agama menolak ilmu pengetahuan. Hal ini diwakili oleh para fundamentaslis yang menyatakan bahwa ilmu pengetahuan merupakan kejatuhan dari dunia sehingga tidak memiliki akses terhadap keberan sejati. Kitab suci merupakan kebenaran yang nyata, seandainya ilmu pengetahuan menolaknya maka itu menjadi malapetaka. 3). Ilmu pengetahuan dan agama mengurus bidang wujud yang berbeda, dengen demikian keduanya dapat hidup berdampiungan secara damai. Artinya wilayah ilmu pengetahuan mengkaji realitas yang terdiri dari berbagai dimensi fisik, yakni tubuh, materi, sedangkan wilayah agama bergulat pada wilayah jiwa dan ruh. 4). Ilmu pengetahuan itu sendiri menawarkan argumen bagi eksistensi spiritual (agama). Pandangan ini mengkalim bahwa bukti ilmiah ataupun penemuan membentangkan tentang relaitias spiritual. Dengan demikian ilmu pengetahuan dapat membantu memahami rahasia tuhan. 5). Ilmu pengetahuan sesunggunya bukanlah pengetahuan tentang dunia, tetapi hanyalah satu dari sekian cara menafsirkan dunia. Oleh karena itu, ia memiliki derajat kesahihan yang sama dengan seni dan puisi, tidak lebih dan tidak kurang. ${ }^{32}$

Menurut Azra dalam konteks Islam agama tidak pernah mengajarkan dikotomi keilmuan. Islam mengajarkan integralisme keilmuan yang disebut dengan "tauhidic paradigm of science" pada tingkat konseptual. Namun harus diakui bahwa pada tingkat praksis tidak jarang di temukannya disharmonisasi, dan dikotomi antara keduanya. Bahkan dikotomi itu sering menjangkau epistimologis, yakni antara wahyu da akal. Atau antara "ilmu-ilmu agama" dengan "ilmu-ilmu umum".

Namun berbagai cabang ilmu dan bentuk-bentuk ilmu pengetahuan dipandangan dari perspektif Islam pada akhirnya adalah satu. Dalam Islam tidak dikenal dengan pemisahan esensi antara "ilmu agama" dengan "ilmu umum". Berbagai disiplin ilmu dan perspektif intlektual yang dikembangkan dalam Islam memang mengandung hirarki tertentu, tapi herarki tersebut pada akhirnya bermuara pada pengetahuan tentang "Hakekat Yang Maha Tunggal" yang merupakan subtansi segenap Ilmu. Inilah kenapa para pemikir muslim berusaha untuk mengintegrasikan ilmu-ilmu yang dikembangkan oleh peradaban-peradaban non muslim kedalam herarki ilmu pengetahuan menurut Islam. ${ }^{33}$

Dalam kontek keislaman konsep integrasi keilmuan ini mempunyai beragam bentuk yang hampir mirip. Seperti halnya Al Attas dan al-Faruqi mengenalkan dengan konsep islamisasi ilmu. Hussien Nasr yang mendasarinya kepada tasawuf ${ }^{34}$, dan Osman Bakar

${ }^{32}$ Ken Wilber, A Theory of Everything : Solusi Menyeluruh atas Masalah Masalah Kemanusiaan, (Bandung : Mizan, 2012) 128-131 dengan judul Asli A theory of everything, an integral vison for business, politics, science, and spirituality.

${ }^{33}$ Azyumardi Azra,"Pengelimpokan Disiplin Ilmu Agama perspektif IAIN" dalam M. Amin Abdullah, dkk. edit. Antologi Studi Islam : Teori dan metodologi, (Yogyakarta : DIP PTA IAIN Sunan Kalijaga, 2000), 159.

${ }^{34}$ Lihat Seyyed Hossein Nasr, Pengetahuan dan Kesucian, Terjemahan Suharsono dkk., Yogyakarta : Pustaka Pelajar dan CSIS, 1997; Seyyed Hossein Nasr, Encounter of Man and Nature, London: Allen and Unwin, 1968. Lihat juga Seyyed Hossien Nasr, The Garden Of Truth : The Vision and Promise of Sufism, Islam's Mystical Tradition (New York : Happer Collins, 2007) xiv 
Qiro'ah| Jurnal Pendidikan Agama Islam

Vol. 11 No. 1 2021| https://ejurnal.iiq.ac.id/index.php/qiroah P-ISSN: 2085-0115 E-ISSN: 2656-3819

DOI: https://doi.org/10.33511/qiroah.v11n1.52-75
Diterima $\quad: 12$ Mei 2021

Direvisi : 17 Mei2021

Disetujui : 03 Juni 2021

Diterbitkan : 12 Juni 2021

menginkan pembedaan penamaan sains islami ${ }^{35}$. Namun semua bentuk konsep tersebut pada hakekatnya semua berasal dari pesan ilahi (alqur'an), yang merupakan sumber intlektualitas dan spiritualitas islam yakni tauhid. Ia bukan hanya merupakan basis bagi agama dan pengetahuan spiritual tetapi bagi semua jenis pengetahuan. Dimana gagasan ini merupakan konsekuensi dari kesatuan semua jenis pengetahuan yang merupakan pengejewantahan dari keesaan Tuhan. al-Qur'an memang bukan merupakan kitab sains tapi ia memberikan pengetahuan tentang prinsip-prinsip sains yang selalu diikat dengan pengetahuan metafisik dan spiritual yang diambil dari ayat pertama "membaca atas nama tuhanmu",36

\section{Nilai Tauhid dalam Biologi}

\section{a. Metode Ilmiah : Memanfaatkan Panca Indra}

Sebelum lebih lanjut menjelaskan tentang metode ilmiah serta kaitannya dengan nilai-nilai tauhid. Penulis akan menjelaskan ruang lingkup biologi kaitannya dengan agama. Menurut Muhammad Amin ${ }^{37}$ untuk menumbuhkan nilai-nilai tauhid dalam belajar biologi, ada tiga tingkatan kesadaran yang harus di bangun yaitu: Pertama, Sadar untuk apa belajar biologi; kesadaran ini berfungsi untuk mengetahui tugas manusia dan fungsi dalam mengelola dan menjaga keseimbangan alam. Kesedaran ini bertujuan untuk menemukan konsep yang jelas dalam belajar biologi, apakah belajar biologi hanya untuk kepetingan pengembangan pengetahuan yang terlepas dari nilai trasenden atau pengembangan pengetahuan ini sarat akan nilai ketuhanan yang menghantarkan manusia mendekatkan diri kepada Allah.

Kedua Sadar akan perlunya konten keilmuan; Kesadaran ini akan menghantarkan manusia tentang pentingnya materi pengetahuan dipelajari dan dikembangkan. Dengan kesadaran ini diharapkan manusia mampu berbuat adil untuk kepentingan pribadi, sosial, ekonomi dan lingkungan dalam mengelola alam.

Ketiga, Sadar akan bagaimana belajar atau mengajar dengan cara/teknik yang benar (how teach/learn the true techique). kesadaran ini menitik beratkan kepada teknik cara mendidik, pentingnya ilmu mendidik itu supaya kesadaran tentang untuk apa belajar biologi dan sadar akan pentingnya konten keilmuan secara simultan dapat dicapai.

Selanjutnya, dalam buku teks mata pelaran biologi digambarkan dengan jelas tentang dimensi tauhid yang ingin dicapai dalam tujuan pembelajaran, yakni mempelajari biologi seseorang dapat memahmi keteraturan dan kerumitan ciptaan Allah Dengan mempelajari biologi anda dapat :

1. Memahami kebesaran ilahi dengan kerumitan dan keteraturan kompleksitas ilmu biologi

\footnotetext{
${ }^{35}$ Lihat Osman Bakar, Tauhid dan Sains : Perspektif Islam tentang Agama \& Sains, judul asli Tawhid and Scince : Islamic Perspective on Religion and Science. (Bandung : Pustaka Hidayah, 2008)

${ }^{36}$ Osman Bakar, Tauhid dan Sains : Perspektif islam tentang Agama \& Sains, judul asli Tawhid and Scince : Islamic Perspective on Religion and Science. (Bandung : Pustaka Hidayah, 2008), 149

\begin{tabular}{l}
$\begin{array}{l}{ }^{37} \text { Mohamad Amin, Perkembangan Biologi dan Tantangan Pembelajarannya, Seminar } \\
\text { Pendidikan dalam }\end{array}$ \\
$\begin{array}{l}\text { Nasional dan } \\
\text { https://publikasiilmiah.ums.ac.id/bitstream/handle/11617/7550/1\%20- }\end{array}$ \\
\hline \%20Moh\%20Amin.pdf?sequence=1(Diakses Tanggal 15 November 2017)
\end{tabular}
}

61 | Qiro’ah Vo. 11 No.1 2021 
Qiro'ah| Jurnal Pendidikan Agama Islam

Vol. 11 No. 1 2021| https://ejurnal.iiq.ac.id/index.php/qiroah P-ISSN: 2085-0115 E-ISSN: 2656-3819

DOI: https://doi.org/10.33511/qiroah.v11n1.52-75
Diterima : 12 Mei 2021

Direvisi : 17 Mei2021

Disetujui : 03 Juni 2021

Diterbitkan : 12 Juni 2021

2. Memahami bioproses dalam kehidupan

3. Memahami cara kerja ilmuwan yaitu kerja ilmiah dan

4. Memperhatikan keselamatan diri sendiri dan orang lain dengan menerapkan aspek keselamatan kerja laboraturium",38

Dalam menelah untuk memahami kerumitan dan keteraturan ciptaan tuhan, dibutuhkan alat atau sarana dalam mencapai tujuan tersebut. Adapun alat dan sarana untuk mencapainya adalah metode ilmiah. Alat dan sarana ini di gunakan oleh para saintis dalam memahami alam semesta dalam bentuk penelitian.

Metode Ilmiah adalah suatu cara sistematis yang digunakan para ilmuan dalam memecahkan atau mencari jawaban atas masalah-masalah yang dihadapi dalam penelitian. Penelitian dapat diartikan sebagai usaha untuk menemukan, mengembangkan, dan menguji kebenaran suatu pengetahuan yang di lakukan dengan menggunakan metode ilmiah. Cara kerja ilmuan ilmuan dengan menerapkan langkah-langkah metode ilmiah, dikenal dengan kerja ilmiah. Kerja ilmiah mencakup dua hal yaitu kemampuan proses penelitian dan kemampuan memanipulasi. Kemampuan proses penelitian meliputi pemikiran secara kritis, kreatif, analitis dan sistematis. Sedangkan kemampuan manipulasi adalah merupakan kemampuan psikomotor untuk penyiasatan dalam penelitian. ${ }^{39}$

Metode ilmiah meliputi kemampuan ilmiah yang dilakukan melalui langkah-langkah tertentu secara sitematis. Langkah tersebut sebagai berikut

1. Menemukan dan merumuskan masalah

2. Menyususn observasi untuk mengumpulkan data untuk mengumpulkan data dan keterangan

3. Menyusun hepotesis

4. Menguji hepotesis melalui percobaan/ekperimeen

5. Menganalisis dan menafsirkan data

6. Menarik kesimpulan

7. Mengomunikasikan hasil penelitian/percobaan

Metode ilmiah yang diberikan dalam buku teks tersebut mengajarkan siswa untuk berfikir logis dan sistematis dalam memahami sebuah objek pengetahuan dalam pencarian kebenaran. Kebenaran tersebut diharapkan siswa mampu memahami kebesaran ilahi, kebesaran ilahi ini berupa ciptaan Allah yang begitu rumit dan teratur.

Menurut penulis metode ilmiah tersebut termasuk cara yang tepat untuk mensyukuri potensi yang dimiliki oleh manusia dalam memanfaatkan panca indra dalam merenungkan ayat-ayat Allah, sebagaimana manusia yang dianugrahi pendengaran, penglihatan dan hati Nurani, ${ }^{40}$

Untuk membedakan manusia dengan makhluk lain adalah potensi akal untuk berfikir dan potensi hati untuk merasakan, dengan potensi tersebut manusia diperintahkan untuk mempelajari dan meneliti agar mampu menguasai, mengendalikan, dan mengambil

\footnotetext{
${ }^{38}$ Buku teks Slamet Prawihartono, Konsep dan Penerapan Biologi SMA/MA kelas Kelas X, Edisi Revisi 2016. (Jakarta : BumiAksara, 2016), 14

${ }^{39}$ Buku teks Slamet Prawihartono, Konsep dan Penerapan Biologi SMA/MA kelas Kelas X, Edisi Revisi 2016. (Jakarta : BumiAksara, 2016), 15

${ }^{40}$ QS. An nahl: 78.
} 
Qiro'ah| Jurnal Pendidikan Agama Islam

Vol. 11 No. 1 2021| https://ejurnal.iiq.ac.id/index.php/qiroah P-ISSN: 2085-0115 E-ISSN: 2656-3819

DOI: https://doi.org/10.33511/qiroah.v11n1.52-75
Diterima $\quad: 12$ Mei 2021

Direvisi : 17 Mei2021

Disetujui : 03 Juni 2021

Diterbitkan : 12 Juni 2021

manfaat dari alam ini secara penuh tanggungjawab untuk kemaslahatan, dan kesejahteraan lahir dan batin seluruh umat manusia.

Cara kerja metode ilmiah adalah melihat gejala-gejala alam untuk diselidiki menggunakan alat ukur. Alat ukurnya adalah berupa pendengaran dan penglihatan untuk mengumpulkan data. Data yang dihasilkan dianalisis sehingga ditemukan pola-pola atau keteraturan-keteraturan. Disusun hipotesis, kemudian dilakukan lagi pengamatan untuk mengumpulkan data, dilakukan interpretasi hingga hipotesis tersebut didukung atau tidak. Sehingga setelah mengalami proses pengujian secara ilmiah diperoleh ilmu pengetahuan alam (sains). Tahap-tahap ini dilakukan secara sistematis. Jika diperhatikan proses dihasilkan oleh sains, maka jelas bahwa sains sangat menekankan pada pengamatan/observasi serta analisis dan interpretasi secara logis dan sistematis secara emperis.

Dalam tataran dogmatis agama, cara kerja ilmiah itu telah Allah perintahkan dalam banyak ayat al-Qur'an, untuk menyelidiki apa yang di langit dan di bumi, diantaranya alQur'an Surat Yunus : 101 "Perhatikanlah apa yaag ada di langit dan di bumi. Tidaklah bermanfaat tanda kekuasaan Allah dan rasul-rasul yang memberi peringatan bagi orangorang yang tidak beriman"

Kemudian diujung ayat tersebut seolah-olah Allah menyayangkan bahwa kenapa menyelidiki apa yang ada di langit dan bumi tidak membawa manusia beriman (menyembah Allah). semestinya dengan mempelajari alam ini. kadar keimanan dan ketaqwaan seorang hamba kepada Allah semakin meningkat.

Metode ilmiah tersebut akan mampu menghantarkan manusia kepada keyakinan, bahwa semua yang diciptakan oleh Allah memiliki kerangka tujuan ilahiyah. Yakni berpijak pada ajaran Tauhid - di mana Allah adalah Pencipta alam semesta, segala sesuatu berasal dari-Nya dan kembali kepada-Nya - seyogyanya setiap langkah yang diambil ditujukan untuk memperoleh keridlaan-Nya dan untuk mendekatkan diri kepada-Nya. Penyelidikan untuk menyingkap rahasia alam semesta tanpa terkecuali terkait dengan kerangka tujuante ini. Al-Qur'an tidak menghendaki penyelidikan terhadap alam semesta hanya untuk pemuasan keinginan (science for science), seperti yang berlaku di Barat. Menurut al-Qur'an, sains hanyalah alat untuk mencapai tujuan akhir. Pemahaman seseorang terhadap alam harus mampu membawa kesadarannya kepada Allah Yang Maha Sempurna dan Maha Tak Terbatas. Dalam perspektif inilah al-Qur'an menampakkan dimensi spiritual dalam kisah Nabi Ibrahim a.s. di dalam surat al-An'am: 76-79.

Keyakinan Tauhid yang kokoh akan membuka cakrawala peneliti kepada pandangan alam yang lebih komprehensif. Ia tidak lagi melihat alam secara parsial dan sebagai bagian yang terpisah dari dirinya, melainkan kesalinghubungan dalam kesatuan di balik keragaman. Inilah yang diisyaratkan al-Qur'an bahwa setiap benda yang diciptakan oleh Allah berada dalam satu kerangka tujuan, sehingga benda terkecilpun memiliki nilai. Ajaran Tauhid juga dapat membimbing manusia kepada kesadaran adanya realitas supranatural di luar realitas eksternal yang dapat diindera. Oleh sebab itu, ada banyak hal yang tidak bisa diraih lewat 
Qiro'ah| Jurnal Pendidikan Agama Islam

Vol. 11 No. 1 2021| https://ejurnal.iiq.ac.id/index.php/qiroah P-ISSN: 2085-0115 E-ISSN: 2656-3819

DOI: https://doi.org/10.33511/qiroah.v11n1.52-75
Diterima $\quad: 12$ Mei 2021

Direvisi : 17 Mei2021

Disetujui : 03 Juni 2021

Diterbitkan : 12 Juni 2021

indera dan dengan demikian tumbuh suatu kesadaran bahwa pada hakekatnya pengetahuan manusia itu sangat terbatas. ${ }^{41}$

\section{b. Keanekaragaman Hayati : Anugrah Keindahan Tuhan}

Penulis akan memaparkan tentang materi keanekaragaman hayati dalam buku teks.

Dalam buku teks dijelaskan bahwa keanekaragaman hayati merupakan sesuatu yang meperlihatkan terdapatnya berbagai perbedaan atau variasi bentuk, penampilan, jumlah, dan sifat-sifat lainnya diantara organisme. Vairasi terbentuk mulai dari satuan tingkatan kehidupan terendah hingga tertinggi, yaitu mulai dari tingkatan gen, jenis, hingga ekosistem. ${ }^{42}$

Keanekaragaman hayati menurut para ilmuan memperkirakan bahwa planet bumi dihuni oleh lebih kurang pulahan juta jenis makhluk hidup. Dari jumlah tersebut, baru sekitar sekitar 1,5 juta jenis yang telah dikenal manusia. Hal yang menarik, dari jutaan jenis makhluk hidup yang menghuni planet, tidak ada dua individu pun yang benar-benar sama untuk segala hal, bahkan dua anak kembar identik sekalipun. Kenyataan tersebut menunjukkan kepada kita, bahwa diplanet bumi dijumpai kenakeragaman hayati atau biodiveritas. Hal ini menunjukkan kebesaran Tuhan Yang Maha Esa pencipta alam semeta ini. Jiki kita memelihara kucing atau ayam, coba perhatiakn ciri-ciri fisik anak kucing atau ayam tersebut. apakah mereka memiliki persamaan dan perbedaan dengan induknya? Tuhan yang Maha Besar telah menciptkan begitu banyak ragam makhluk hidup yang memiliki fungsi dan peran masing-masing didalam kehidupan. Pernahkah kita berfikir berapa banyak jumlah jenis flora dan fauna yang ada dibumi ? Kelimpahan keanekaragaman hayati patut kita syukuri, salah satunya adalah dengan cara memanfaatkan potensi keanekaragaman hayati tanpa merusak atau mengurangi kelestariannya. ${ }^{43}$

Jadi secara luas keanekaragaman hayati merupakan beraneka macam mahluk hidup di bumi ini. Keanekaragaman hayati dapat terjadi pada berbagai tingkat kehidupan, mulai dari organisme tingkat rendah sampai organisme tingkat tinggi. Misalnya dari mahluk bersel satu hingga mahluk bersel banyak; dan tingkat organisasi kehidupan individu sampai tingkat interaksi kompleks, misalnya dari spesies sampai ekosistem. Banyaknya keanekaragaman mahluk hidup ini meyebabkan diperlukannya pengenalan lebih dini kepada siswa untuk menyadarinya melalui pembelajaran di sekolah.

Para ilmuan membagi keanekaragaman hayati di bagi menjadi tiga tingkatan yaitu :

1. Keanekaragaman Gen

Keanekaragaman gen adalah variasi atau perbedaan gen dalam satu jenis atau spesies makhluk hidup. perbedaan komposisi dan jumlah komponen kerangka dasar tersebut menyebabkan terjadinya keanekafragaman gen. akibat selanjutnya adalah dihasilkan variasi tampilan makhluk hidup dalam satu spesesies.

2. Keanekaragaman jenis

\footnotetext{
${ }^{41}$ Jamal Fakhri, "Sains dan Teknologi Dalam Al-Qur'an dan Implikasinya dalam Pembelajaran", Ta'dib, Vol. XV No. 01. Edisi, Juni 2010. 121-141.

${ }^{42}$ Lihat buku teks Slamet Prawihartono, Konsep dan Penerapan Biologi SMA/MA kelas Kelas X, Edisi Revisi 2016. (Jakarta : BumiAksara, 2016. 31

${ }^{43}$ Lihat buku teks Slamet Prawihartono, Konsep dan Penerapan Biologi SMA/MA kelas Kelas X, Edisi Revisi 2016. (Jakarta : BumiAksara, 2016. 31
} 
Qiro'ah| Jurnal Pendidikan Agama Islam

Vol. 11 No. 1 2021| https://ejurnal.iiq.ac.id/index.php/qiroah P-ISSN: 2085-0115 E-ISSN: 2656-3819

DOI: https://doi.org/10.33511/qiroah.v11n1.52-75

$\begin{array}{ll}\text { Diterima } & : \text { 12 Mei } 2021 \\ \text { Direvisi } & : 17 \text { Mei2021 } \\ \text { Disetujui } & : \text { 03 Juni } 2021 \\ \text { Diterbitkan } & : \text { 12 Juni } 2021\end{array}$

Keanekaragaman ini lebih mudah diamati daripada Keanekaragaman gen. Keanekaragaman hayati tingkat ini dapat ditunjukkan dengan adanya beraneka macam jenis mahluk hidup baik yang termasuk kelompok hewan, tumbuhan dan mikroba.misalnya variasi dalam satu famili antara kucing dan harimau. Mereka termasuk dalam satu famili(famili/keluarga Felidae) walaupun ada perbedaan fisik, tingkah laku dan habitat

3. Keanekaragaman Ekosistem

Keanekaragaman tingkat ini dapat ditunjukkan dengan adanya variasi dari ekosistem di biosfir.misalnya : ekosistem lumut, ekosistem hutan tropis, ekosistem gurun, masing-masing ekosistem memiliki organisme yang khas untuk ekosistem tersebut. misalnya lagi, ekosistem gurun di dalamnya ada unta, kaktus, dan ekosistem hutan tropis di dalamnya ada dalamnya ada harimau.Ketiga macam keanekaragaman tersebut tidak dapat dipisahkan satu dengan yang lain.

Ketiga tingkat keanekaragaman hayati dipandang sebagai suatu keseluruhan atau totalitas yaitu sebagai Keanekaragaman hayati. Maksud dari konsep ini adalah :

a. Dengan mengetahui adanya keanekaragamaan gen merupakan modal dasar untuk melakukan rekayasa genetika dan hibridisasi (kawin silang) untuk mendapatkan bibit unggul yang diharapkan.

b. Dengan mengetahui adanya kenaekaragaman jenis dapat menuntun kita untuk mencari alternatif dari bahan makanan, bahan sandang, dan papan, juga dapat menuntun kita memilih hewan-hewan unggul yang dapat dibudidayakan.

c. Dengan mengetahui adanya keanekaragaman ekosistem kita dapat mengembangkan sumber daya hayati yang cocok dengan ekosistem tertentu sehingga dapat meningkatkan hasil pertanian dan peternakan yang pada gilirannya dapat meningkatkan kesejahteraan masyarakat.

Dari penjelasan di atas, penulis memaparkan bahwa keanekaragaman hayati dapat diartikan sebagai variasi segala macam dan keanekaragaman seluruh ciptaan Allah Swt di muka bumi ini, baik yang terdiri dari alam binatang maupun alam tumbuhan. Ketika keanekaragaman hayati diintegrasikan kedalam agama. Maka keanekaragaman hayati tersebut bisa dilihat dalam al-Qur'an, pada term-term yang dipakai untuk menunjukkannya yang diungkapkan secara implisit dan eksplisit. Ungkapan yang implisit ditunjukkan oleh informasi berbagai ragam makhluk yang diciptakan Allah. Misalnya pada Q.S. al-Tin ayat 1 alQur'an menyebut buah tin dan zaitun, Q.S al-Ana'm [6]: 99, menyebut buah anggur, delima dan zaitun. Sementara itu, untuk penyebutan secara eksplist al-Qur'an menggunakan term mukhtalif alwanuh (berbeda-beda macam warnanya) seperti dalam Q.S. al-Rum [30]: 22), QS. Fathir [35]:27, ${ }^{44}$

Dari penjelasan tersebut diharapkan siswa memiliki tingkat pemahaman secara holistik, bahwa nilai-nilai tauhid bisa di lihat dari materi pelajaran biologi dengan melihat beberapa penjelasan ayat tersebut. Dengan demikan ulusan materi keanekaraman hayati dari materi biologi dan agama tersebut bisa di tarik kesimpulan yakni keanekaragaman hayati sebagai anugerah karunia Allah Swt. Betapa Tuhan begitu kasih dan sayang kepada manusia, sehingga semua jenis dan ragam hayati disediakan untuk kemaslahatan dalam kehidupan

\footnotetext{
${ }^{44}$ Abdul Mustaqim, "Etika Pemanfaatan Keakekaragaman Hayati Dalam Perspektif AlQur'an", Hermeneutik, Vol. 9, No.2, Desember 2015. 398.
} 
Qiro'ah| Jurnal Pendidikan Agama Islam

Vol. 11 No. 1 2021| https://ejurnal.iiq.ac.id/index.php/qiroah P-ISSN: 2085-0115 E-ISSN: 2656-3819

DOI: https://doi.org/10.33511/qiroah.v11n1.52-75
Diterima $\quad: 12$ Mei 2021

Direvisi : 17 Mei2021

Disetujui : 03 Juni 2021

Diterbitkan : 12 Juni 2021

manusia untuk mengemban kekhalifahan di muka bumi ini. Namun ingat, bahwa manusia harus pandai mensyukuri keberadaanya, ${ }^{45}$ dan memanfaatkannya dengan sebaik-baiknya. Jangan sampai keanekaragaman tersebut dirusak hanya karena mengikuti selera rendah, sehingga bisa menjadi bencana dan siksa yang merugikan manusia sendiri. ${ }^{46}$ Kedua, sebagai tanda-tanda kekuasaan Allah (signs of Allah/ ayatun min ayatillah), yang harus diambil pelajaran darinya, untuk direnungkan dan dipikirkan betapa kuasa Allah luar biasa dalam penciptaannya.

Disamping itu, berbagai keanekaragaman harus dipelajari, apa sebenarnya hikmah dan manfaatnya bagi manusia, sebab Tuhan tidak menciptakan semua makhlukNya dengan sia-sia. Dengan demikian, merusak keanekaragman hayati berarti sama dengan menghilangkan ayat-ayat Tuhan di muka bumi ini. Sebaliknya, memelihara dan merawatnya menjadi salah satu indikator ketakwaan seseorang terkait dengan keanekaragaman hayati, sebagaimana disyaratkan dalam akhir bahwa pergantian siang malam dan keanekaragaman ciptaan Allah benar-benar terdapat tanda-tanda (kekuasaan-Nya) bagi orang- orang yang bertakwa. ${ }^{47}$

Dari belajar keanekaragaman hayati tersebut, seseorang akan mampu memperlakukan alam dengan segala spesiesnya dengan baik, sebab melindungi dan melestarikan keanekaragaman hayati adalah bentuk ibadah. Agama yang merupakan penggerak untuk melindungi keanekaragaman tersebut tetap menjadi salah satu dari sumbersumber penting bagi manusia. Agama memberikan hubungan atau identifikasi antara manusia dan lingkungan yang menjadi perantara dengan alam dan makhluk yang lain untuk memahami sehingga menjadikan pelestarian bukan penghancuran ${ }^{48}$

Ketika berbicara tentang keanekaraman hayati islam memiliki etika dalam pengelolaannya dan pengembangannaya. Menurut Chandra Singh Negi mengatakan bahwa etika Islam memiliki dua prinsip tentang hubungan antara alam,manusia, agama dan alasan hukum, prinsip pertama adalah naluri alami ( fitrah). Hal itu tercetak dalam jiwa manusia dengan Tuhan pada saat penciptaan. Secara alami setiap individu setidaknya dapat membedakan tidak hanya antara baik dan buruk, tetapi juga antara apa yang netral. Kedua adalah etika dalam Islami tidak didasarkan pada berbagai kebajikan yang terpisah-pisah, namun kebajikan dalam Islam merupakan totalitas dalam melakukan segala sesuatu, termasuk cara hidup yang komprehensif, yang berfungsi untuk membimbing dan mengendalikan semua aktivitas manusia sehingga kebenaran adalah nilai etika, seperti melindungi kehidupan, melestarikan lingkungan dan mempertahankan perkembangannya dalam batas-batas apa yang Allah telah perintahkan. ${ }^{49}$

\section{c. Ekologi (ekosistem ) : Keseimbangan dan Keteraturan Alam Semesta}

\section{${ }^{45}$ Q.S. Ibrahim : 7}

${ }^{46}$ Q.S. al-Rum :41

${ }^{47}$ Abdul Mustaqim, "Etika Pemanfaatan Keakekaragaman Hayati Dalam Perspektif AlQur'an", Hermeneutik, Vol. 9, No.2, Desember 2015, 400.

${ }^{48}$ Bratton SP. Monks, temples, and tress- the spirit of diversity. In Meffe GK and Carroll CR (eds), Principles of Conservation Biology. Sunderland, USA: Sinauer Associates Inc.; 1999:40-1

${ }^{49}$ Chandra Singh Negi, Religion and biodiversity conservation: not a mere analogy dalam https://doi.org/10.1080/17451590509618083 (diakses 2 februari 2018) 
Qiro'ah| Jurnal Pendidikan Agama Islam

Vol. 11 No. 1 2021| https://ejurnal.iiq.ac.id/index.php/qiroah P-ISSN: 2085-0115 E-ISSN: 2656-3819

DOI: https://doi.org/10.33511/qiroah.v11n1.52-75

$\begin{array}{ll}\text { Diterima } & : \text { 12 Mei } 2021 \\ \text { Direvisi } & : 17 \text { Mei2021 } \\ \text { Disetujui } & : \text { 03 Juni } 2021 \\ \text { Diterbitkan } & : \text { 12 Juni } 2021\end{array}$

Dalam buku teks biologi desebutkan bahwa ekologi adalah istilah yunani, oikoe $=$ rumah, dan logos = ilmu yang pertama kali diperkenalkan oleh Haeckel pada pertengahan dasawarsa 1860-an. Secara harfiah, ekologi dapat diartikan ilmu tentang makhluk hidup dalam rumahnya, atau ilmu tentang rumah tangga makhluk hidup. Namun, secara sederhana ekologi dapat diartikan sebagai ilmu tentang hubungan timbal balik antara makhluk hidup dengan lingkungannya.

Hubungan timbal balik antara makhluk hidup dengan lingkungannya merupakan suatu kesatuan fungsional, artinya komponen yang satu dengan lainnya saling berintraksi membentuk suatu sistem, yang dikenal dengan ekosistem. Jadi objek ekologi itu adalah ekosistem tersebut. Suatu daerah dapat disebut ekosistem kalau daerah itu dihuni oleh makhluk hidup. Dengan demikian komponen ekosistem terdiri atas benda mati/tidak hidup (komponen abiotic) dan makhluk hidup (komponen biotik) ${ }^{50}$

Komponen abiotic adalah komponen yang terdiri atas benda-benda tidak hidup, seperti tanah, air, udara cahaya, suhu serta keadaan yang terbentuk sebagai hasil intraksi dari berbagai benda tak hidup seperti kelembapan, arus angina, drajat keasaman, iklim,, topografi, arus air, daln lain-lain ${ }^{51}$ sedangkan komponen Komponen biotik merupakan semua makhluk hidup yang berada pada suatu daerah.Setiap makhluk hidup hanya dapat hidup dan berkembang baik pada lingkungan yang sesuai, untuk mengetahui tempat hidupnya sebuah makhluk hidup yakni daerah dimana suatu organisme biasanya hidup dan mengembangkan diri disebut habitat. Komponen biotik dapat berupa tumbuhan, hewan, mikrooganisme, manusia, hewan, tumbuhan, didalam ekosistem, setiap organisme mempunyai peranan atau fungsi tertentu. Fungsi makhluk hidup dalam suatu ekosistem disebut nisia atau relung

Berdasarkan nisianya organisme dalam suatu ekosistem dapat dibedakan menjadi empat macam, yakni produsen ; organisme yang dapat menyusun senyawa organic atau membuat zat makanan sendiri, melalui proses fotosintesis. Karena organisme produsen mampu menghasilkan zat makanan sendiri maka sering disebut organisme autotrof. Konsumen; organisme yang tidak mampu membuat zat makan sendiri, untuk memenuhi kebutuhan makannya, organisme ini bergantung kepada organisme lain, karenya sering disebut organisme heterotroph. Konsumen yang makannnya hewan lain disebut karnivora. Kunsumen yang makannya berupa segalanya (hewan dan tumbuhan), sisebut omnivoira. Konsumen yang hidup dalam jaringan organisme lain dan merugikan disebut parasite. Detretivor ; organisme yang menamkan sisa organisme lain atau detritus. Detritus ini merupakan hancuran jaringan hewan yang atau tumbuhan yang melapuk. Yang masuk dalam katagori golongan ini adalah cacing tanah, siput, lipan, keluwing, dan teripang. Decomposer atau perombak ; organisme yang bertugas menghancurkan partikel-partikel organisme lain dengan menghasilkan enzim. Yang termasuk dalam golongan ini adalah bakteri dan jamur. ${ }^{52}$

${ }^{50}$ Lihat buku teks Slamet Prawihartono, Konsep dan Penerapan Biologi SMA/MA kelas Kelas X, Edisi Revisi 2016. (Jakarta : BumiAksara, 2016), 231

${ }^{51}$ Lihat buku teks Slamet Prawihartono, Konsep dan Penerapan Biologi SMA/MA kelas Kelas X, Edisi Revisi 2016. (Jakarta : BumiAksara, 2016),231.

${ }^{52}$ Lihat buku teks Slamet Prawihartono, Konsep dan Penerapan Biologi SMA/MA kelas Kelas $X$, Edisi Revisi 2016. (Jakarta : BumiAksara, 2016),236. 
Qiro'ah| Jurnal Pendidikan Agama Islam

Vol. 11 No. 1 2021| https://ejurnal.iiq.ac.id/index.php/qiroah P-ISSN: 2085-0115 E-ISSN: 2656-3819

DOI: https://doi.org/10.33511/qiroah.v11n1.52-75

$\begin{array}{ll}\text { Diterima } & : \text { 12 Mei } 2021 \\ \text { Direvisi } & : 17 \text { Mei2021 } \\ \text { Disetujui } & : \text { 03 Juni 2021 } \\ \text { Diterbitkan } & : \text { 12 Juni 2021 }\end{array}$

Komponen biotik dan abiotik ini merupakan elemen dasar dalam membentuk ekosistem, tidak dapat di pungkiri bahwa komponen tersebut. pada awalnya faktor abiotik yang menyokong kehidupan tumbuh-tumbuhan sebagai produsen; kemudian tumbuhtumbuhan menjadi penyokong kehidupan organisme lainnya (binatang dan manusia) sebagai konsumen maupun detritivora, dan akhirnya decomposer (bakteri dan jamur) mengembalikan unsur-unsur pembentuk makhluk hidup kembali ke alam lagi menjadi faktor-faktor abiotik; demikian seterusnya terjadilah daur ulang materi dan aliran energi di alam secara seimbang. Sumber energi untuk kehidupan di bumi adalah energi matahari, kemudian diikat dan digunakan oleh tumbuhan untuk mensintesis zat-zat anorganik sederhana menjadi zat-zat organic yang mengandung energi. Kandungan materi dan energi dari tumbuhan tersebut dipindahkan ke hewan atau manusia melalui proses rantai makanan dan jaring-jaring kehidupan, yang akhirnya materi dan energi kembali beredar lagi ke alam melalui proses pembusukan / perombakan yang dilakukan oleh decomposer / pengurai. ${ }^{53}$

Berdasarkan uraian diatas, setiap komponen memiliki ketergantungan satu sama lain, antara komponen abiotic dan biotik. Ketergantungan antara komponen biotik dapat terjadi melalui pertama rantai makanan, yaitu perpindahan materi dan energi melalui proses makan dan dimakan oleh urutan tertentu. Setiap tingkat dari rantai makanan disebut tingkat trofi atau tingkat trofi. Karena organisme pertama yang mampu menghasilkan zat makanan nabati, tingkat trofi pertama selalu diduduki oleh tanaman hijau sebagai produsen. Kedua Jaring makanan, yaitu rantai makanan yang saling berhubungan satu sama lain untuk membentuk net. Jaring makanan terjadi karena setiap spesies hidup tidak hanya makan satu jenis makhluk hidup lainnya.

Ketergantungan ini akan membentuk system keseimbangan alam. Keseimbangan ini terbentuk dari ekosistem yakni unsur lingkungan hidup yang merupakan kesatuan utuh menyeluruh dan saling mempengaruhi dalam membentuk keseimbangan, stabilitas, dan produktivitas lingkungan hidup. Ciri-ciri adanya ekosistem adalah berlangsungnya pertukaran dan transformasi energi yang sepenuhnya berlangsung di antara berbagai komponen dalam sistem itu sendiri atau dengan sistem lain di luarnya. ${ }^{54}$

Dengan demikian dalam teks tersebut menjelaskan tentang bagaimana hubungan timbal-balik antara makhluk hidup dengan yang lainnya saling membutuhkan, dimensi tauhid pada materi tersebut penulis menyebutnya dengan sistem keteraturan yakni bagaimana suatu makhluk kehidup bergantung dengan kehidupan yang lain. Ekologi ini sarat akan nilai-nilai tauhid. Nilai tauhid tersebut ada pada keteraturan alam semesta, yakni hubungan timbal balik antar komponenen ekosistem yang mengakibatkan terebentuknya tingkatan-tingkatan organisasi kehidupan. ${ }^{55}$ Inilah nilai dasar yang harus di miliki seseorang yakni saling membutuhkan, dalam al-qur'an "Allah-lah yang telah menciptakan langit dan bumi dan menurunkan air hujan dari langit, kemudian Dia mengeluarkan dengan air hujan itu berbagai buah-buahan menjadi rezeki untukmu; dan Dia telah menundukkan bahtera

${ }^{53}$ Lihat buku teks Slamet Prawihartono, Konsep dan Penerapan Biologi SMA/MA kelas Kelas X, Edisi Revisi 2016. (Jakarta : BumiAksara, 2016),231-357

${ }^{54}$ Lihat buku teks Slamet Prawihartono, Konsep dan Penerapan Biologi SMA/MA kelas Kelas $X$, Edisi Revisi 2016. (Jakarta : BumiAksara, 2016),231-357

${ }^{55}$ Lihat buku teks Slamet Prawihartono, Konsep dan Penerapan Biologi SMA/MA kelas Kelas $X$, Edisi Revisi 2016. (Jakarta : BumiAksara, 2016), 238. 
Qiro'ah| Jurnal Pendidikan Agama Islam

Vol. 11 No. 1 2021| https://ejurnal.iiq.ac.id/index.php/qiroah P-ISSN: 2085-0115 E-ISSN: 2656-3819

DOI: https://doi.org/10.33511/qiroah.v11n1.52-75
Diterima $\quad: 12$ Mei 2021

Direvisi : 17 Mei2021

Disetujui : 03 Juni 2021

Diterbitkan : 12 Juni 2021

bagimu supaya bahtera itu, berlayar di lautan dengan kehendak-Nya, dan Dia telah menundukkan (pula) bagimu sungai-sungai. Dan Dia telah menundukkan (pula) bagimu matahari dan bulan yang terus menerus beredar (dalam orbitnya); dan telah menundukkan bagimu malam dan siang." $" 56$

Allah menciptakan dengan sedemikian rupa satu komponen pokok dalam ekositem yang satu sama lain mebutuhkan. Komponen pokok penyusun materi dan fenomena dasar melibatkan komponen dasar yang melibatkan komponen tersebut semuanya saling terhubung, terkait, dan bergantung satu sama lain.

Komponen itu tak bisa di pahami sebagai entensitas terisolir, namun hanya sebagai bagian terintegrasi dari satu keseluruhan. Kesadaran akan kesatuan dan hubungan timbal balik dari segala sesuatu, benda dan peristiwa, pengalaman atas seluruh fenomena didunia sebagai manifestasi dari satu kesatuan dasar. ${ }^{57}$

Keteraturan itu merupakan bukti tasbihnya alam semesta ini. Keteraturan ini seperti adanya mikroba atau organisme yang mendaur ulang bangkai yang menjadikan tanah tersebut subur, manfaat energi matahari sebagai sumber makan oleh tumbuhan dengan menggunakan proses fotosintesis. Al-quran memberikan informasi secara implisit tentang apa yang ada dialam semesta ini untuk dijadikan sebuah renungan yang berkaitan dengan tumbuh-tumbuhan "Dan Dialah yang menurunkan air hujan dari langit, lalu Kami tumbuhkan dengan air itu segala macam tumbuh-tumbuhan maka Kami keluarkan dari tumbuh-tumbuhan itu tanaman yang menghijau. Kami keluarkan dari tanaman yang menghijau itu butir yang banyak; dan dari mayang korma mengurai tangkai-tangkai yang menjulai, dan kebun-kebun anggur, dan (Kami keluarkan pula) zaitun dan delima yang serupa dan yang tidak serupa. Perhatikanlah buahnya di waktu pohonnya berbuah dan (perhatikan pulalah) kematangannya.Sesungguhnya pada yang demikian itu ada tanda-tanda (kekuasaan Allah) bagi orang-orang yang beriman," ${ }^{58}$.

Kehidupan ini adalah system, sifat-sifat dasar sebuah organisme, atau system hidup. Ini adalah sifat-sifat keseluruhan, yang tidak dimiliki oleh bagian-bagian. Sifat-sifat itu muncul dari intraksi dan hubungan antara bagian-bagian. Sifat-sifat itu akan rusak ketika system tersebut dibedah baik secara fisik maupun teroritis, menjadi unsur-unsur yang terpisah-pisah. Walalupun bisa dilihat maupun dikenal individual atau system apapun, bagian-bagian ini tak akan bisa terpisah-pisah, dan sifat dasar keseluruhan senantiasa berbeda-beda dari sekedar jumlah bagian-bagiannya. ${ }^{59}$

Dari beberapa penjelasan diatas penulis memberikan sebuah kesimpulan bawa adanya fenomena daur ulang materi dan siklus energi di alam, keajaiban daur hidup pada tumbuhan maupun hewan, dan berbagai bentuk keanekaragaman makhluk hidup dengan kemampuan adaptasinya, memberikan petunjuk adanya Tuhan Yang Maha Kuasa sehingga

\footnotetext{
${ }^{56}$ QS. Ibrahim: 32-33

${ }^{57}$ Fritjof Capra, The Tao of Physics : Menyingkap Kesejajaran Fisika Modern Dan Mistisme Timur, (Yogyakarta : Jalasutra, 2000), 127.

${ }^{58}$ Q.S. Al-An'am Ayat : 99

${ }^{59}$ Fritjof Capra, Jaring-Jaring Kehidupan : Visi Baru Epestimologi dan Kehidupan, (Yogyakarta : fajar pustaka baru, 2002),46
} 
Qiro'ah| Jurnal Pendidikan Agama Islam

Vol. 11 No. 1 2021| https://ejurnal.iiq.ac.id/index.php/qiroah P-ISSN: 2085-0115 E-ISSN: 2656-3819

DOI: https://doi.org/10.33511/qiroah.v11n1.52-75
Diterima $\quad: 12$ Mei 2021

Direvisi : 17 Mei2021

Disetujui : 03 Juni 2021

Diterbitkan : 12 Juni 2021

manusia wajib menyembahNya dan taat kepada firman-firmanNya. ${ }^{60}$ Setelah membandingkan struktur berbagai jenis makhluk hidup yang dalam ekosistem, manusia wajib mensyukuri atas penciptaan manusia sebagai makhluk hidup yang paling sempurna dibandingkan organisme lainnya sehingga sepatutnya meningkatkan keimanan dan ketaqwaan kepada Allah swt. Disamping itu manusia harus mempu menjaga amanah dari sang pencipta, untuk menjaga dan keberlangsungan dan mememnuhi hajat hidupnya, manusia mempunyai ha untuk memanfaatkan apa yang ada dimuka bumi (sumber daya alam). Tapi manusia secara individu maupun kelompok tidak mempunyai hak mutlak untuk menguasai sumber daya alam yang bersangkutan. Hak penguasaannya tetap ada pada Tuhan Pencipta. Manusia wajib amanah yang telah di berikan oleh Tuhan. sehingga dalam konteks ini alam merupakan tempat tinggal manusia agar manusia bisa berhasil baik dalam ujiannya, maka ia harus bisa membaca "tanda-tanda" atau "ayat-ayat" alam yang ditunjukkan oleh sang Maha Pengatur Alam.

\section{d. Keseimbangan Lingkungan (Ekosistem) : Menjaga dan Merawat Pemberian Tuhan}

Pada sub ini, permasalahan lingkungan akan dipelajari yang meliputi kerusakan dan pencemaran lingkungan, mendiskusikan penyebab terjadinya kerusakan dan pencemaran lingkungan, membahas dampak kerusakan, memberikan saran dan masukan alternatif cara mengatasi kerusakan dan cara pencemaran, serta akan mempelajari cara melestartarikan lingkungan dan etika lingkungan.

Dalam buku teks ini definisi lingkungan merupakan suatu kesatuan ruang dengan semua komponen biotik dan komponen abiotic, daya, keadaan, termasuk manusia dan prilakunya yang mempengaruhi kesejehteraan dan kelangsungan hidup manusia dan makhluk hidup lainnya. Dalam keseimbangan lingkungan yang normal dan alami, akan senantiasa menjamin terjadinya berbagai dinamika kehidupan, seperti rantai makanan, jaring-jaring makanan, produktivitas, daur materi, aliran energy, piramida makanan, dan lain-lain, semua dinamika memungkinkan proses kehidupan terus berlangsung dan berkesinambungan. Dinamika tersebut menunjukkan bahwa antar komponen dan ekosistem senantiasa terjadi intraksi dan akan membentuk keseimbangan lingkungan. Keseimbangan lingkungan adalah kemampuan lingkungan untuk mengatasi tekanan dari alam maupun dari aktivitas manusia, serta kemampuan lingkungan untuk menjaga kestabilan kehidupannya. ${ }^{61}$

Dalam teks buku tersebut ada dua factor yang menyebabkan terjadinya perubahan lingkungan yaitu prilaku manusia dan peristiwa yang terjadi secara alami. Prilaku manusia yang menjadikan membuat perusakan adalah diakibatkan meningkatnya populasi manusia, sehingga menyebabkan kebutuhan hidup manusia meningkat. Pemenuhan kebutuhan tersebut diperoleh dari lingkungan. Berkembangnya ilmu dan teknologi menyebabkan manusia mudah dalam mengekplotasi sumberdaya daya lingkungan. Peningkatan pemenuhan kebutuhan tersebut makin besar pengaruhnya terhadap kerusakan keseimbangan alam.

\footnotetext{
${ }^{60}$ Lihat buku teks Slamet Prawihartono, Konsep dan Penerapan Biologi SMA/MA kelas Kelas $X$, Edisi Revisi 2016. (Jakarta : BumiAksara, 2016), 252-257

${ }^{61}$ Buku teks, Slamet Prawihartono, Konsep dan Penerapan Biologi SMA/MA kelas Kelas X, Edisi Revisi 2016. (Jakarta : BumiAksara, 2016), 263
} 
Qiro'ah| Jurnal Pendidikan Agama Islam

Vol. 11 No. 1 2021| https://ejurnal.iiq.ac.id/index.php/qiroah P-ISSN: 2085-0115 E-ISSN: 2656-3819

DOI: https://doi.org/10.33511/qiroah.v11n1.52-75

$\begin{array}{ll}\text { Diterima } & : \text { 12 Mei } 2021 \\ \text { Direvisi } & : 17 \text { Mei2021 } \\ \text { Disetujui } & : \text { 03 Juni 2021 } \\ \text { Diterbitkan } & : \text { 12 Juni 2021 }\end{array}$

Hal ini juga diperparah oleh berbagai sikap manusia yang sedang cenderung ingin memenuhi keinginannya melalui cara yang dapat merusak lingkungan. Beberapa contoh prilaku manusia yang berdampak besar terhdap perubahan lingkungan diantaranya, pembabatan dan pembakaran hutan, penggunaan pestisida, penggunaan pupuk buatan yang berlebihan, penyederhanaan ekosistem. kedua adalah peristiwa alam. Tidak semua perubahan keseimbangan ekosistem karena pongaruh tingkahlaku manusia saja, ada beberapa peristiwa penyebab perubahan lingkungan yang diluar campur tangan manusia, yakni peristiwa kemarau panjang, musim penghujan panjang, musim dingin yang berlebihan, bencana angin putting beliung, banjir bandang, bencana gunung meletus, peristiwa gempa bumi dan tsunami. ${ }^{62}$

Manusia merupakan salah satu komponen lingkungan hidup yang memiliki ciri yang sangat berbeda dengan komponen lingkungan lainnya. Perbedaan yang sangat hakiki dengan makhluk hidup lainnya adalah manusia memiliki akal atau kecerdikan. Sebagai homo sapiens, spesies ini mempunyai peran yang begitu dominan dalam kehidupan ekologis bumi.

Sebagai mahluk yang dominan manusia banyak menentukan corak kehidupan ekosistem, ia dapat menaklukkan ekosistem alamiah satu dengan yang lain, menjelajah keseluruh bagian ekosistem dibanyak tempat di bumi, seperti gedung-gedung, kawasan industry, pemikiman, kota, desa, pertanian dan sebagainy. Ini disebut dengan ekosistem buatan yang bersifat fisik.

Selain menciptakan ekosistem yang bersifat fisik, manusia mampu pulamenciptakan ekosistem nonfisik dalam berbagai corak, kepentingan, kebiasaan, nilai, adat istiadat, keyakinan, pandangan hidup dan tata kelakuan lain. Kedalam ekositem inilah dikenal dengan berbagai ekosistem seperti ekosistem politik, ekositem agama, eskositem ekonomi, ekositem kebudayaan, ekosistem kapitalisme, ekosistem kapitalisme marxisme, dan lain sebaginya.

Alam diciptakan Allah dalam keberagaman kualitatif maupun kuantitatif seperti ukuran, jumlah, struktur, peran, umur, jenis kelamin, masa edar dan radius edarnya. Walaupun demikian, alam dan ekosistem ciptaan Tuhan yang sangat beragam ini berada dalam keseimbangan, baik keseimbangan antar individu maupun antar kelompok. Keseimbangan ini merupakan hukum Tuhan yang juga berlaku atas alam termasuk manusia. Keseimbangan ini bisa mengalami gangguan (disharmoni) jika salah satu atau banyak anggota kelompok atau suatu kelompok mengalami gangguan baik secara alamiah (karena sebab-sebab yang alamiah) maupun akibat campur tangan manusia. ${ }^{63}$

Jika terjadi gangguan terhadap keseimbangan alam, maka alam akan bereaksi atau merespon dengan membentuk keseimbangan baru yang bisa terjadi dalam waktu singkat, atau bisa pula dalam waktu yang cukup lama tergantung pada intensitas gangguan serta sifat kepentingan masing-masing sistem alam yang bersangkutan. Keseimbangan baru yang terbentuk ini sudah barang tentu bisa berbeda secara kuantitatif maupun kualitatif dengan keseimbangan sebelumnya. Demikian pula keseimbangan baru ini bisa bersifat merugikan,

\footnotetext{
${ }^{62}$ Lihat buku teks Slamet Prawihartono, Konsep dan Penerapan Biologi SMA/MA kelas Kelas $X$, Edisi Revisi 2016. (Jakarta : BumiAksara, 2016), 63

${ }^{63}$ Jumarddin La Fua, Aktualisasi Pendidikan Islam dalam Pengelolaan Lingkungan Hidup Menuju Kesalehan Ekologis Jurnal, Al-Ta'dib Vol. 7 No. 1 Januari-Juni, 19-35, http://ejournal.uinsuka.ac.id/tarbiyah/JPI/article/download/1194/1090 (diakses tanggal 12 Februari 2018
} 
Qiro'ah| Jurnal Pendidikan Agama Islam

Vol. 11 No. 1 2021| https://ejurnal.iiq.ac.id/index.php/qiroah P-ISSN: 2085-0115 E-ISSN: 2656-3819

DOI: https://doi.org/10.33511/qiroah.v11n1.52-75

$\begin{array}{ll}\text { Diterima } & : \text { 12 Mei } 2021 \\ \text { Direvisi } & : 17 \text { Mei2021 } \\ \text { Disetujui } & : \text { 03 Juni 2021 } \\ \text { Diterbitkan } & : \text { 12 Juni 2021 }\end{array}$

bisa pula menguntungkan bagi anggota komunitas atau kelompok yang bersangkutan. Perilaku dan perbuatan manusia terhadap alam termasuk antar manusia yang diharamkan (dilarang), sebenarnya bertujuan agar keseimbangan atau harmoni alam tidak mengalami gangguan. ${ }^{64}$

Dalam Islam misalnya, terdapat beberapa landasan teologis-normatif bagaimana alam diciptakan dan dikelola. Ayat-ayat al-Qur'an yang berbicara tentang lingkungan hidup secara kualitatif dapat dikelompokkan ke dalam tiga klasifikasi, yaitu; pertama, ayat tentang proses terjadinya lingkungan, kedua, ayat tentang pengelolaan lingkungan, dan ketiga, ayat tentang pelestarian dan perusakan lingkungan ${ }^{65}$

Selain itu agama islam sebagai ajaran yang menanamkan nilai-nilai tauhid, maka sudah pasti berusaha untuk menjaga amanah agar memelihara alam, hal ini merupakan manifestasi rasa syukur manusia kepada tuhan. sebab islam adalah agama yang menjunjung nilai-nilai syukur, maka dari awal kelahirannya, sudah mengajarkan untuk memelihara dan menjaga keseimbangan alam. Selanjutnya untuk menumbuhkan kembali kesadaran spiritualitas menjaga alam untuk memberikan sumbangan dan berperan serta dalam tanggung jawab etis di bidang penyelamatan lingkungan. Pengendalian diri dalam pengeksploitasian alam atau lingkungan dinilai dari lahir dan berkembangnya pemikiran serta semangat itu termasuk didalamnya menanamkan kesadaran dalam pengelolaan lingkungan hidup ${ }^{66}$.

Bencana lingkungan yang terjadi saat ini diakibatkan oleh akumalasi beban yang terlalau berat sehingga keauatan penahan dilampaui. Penyebab bencana lingkungan dapat dikabatkan oleh alam dan ulah manusia. Penyebab bencana oleh manusia dalam menempatkan sebidang lahan sesuai dengan fungsi dan kemampuanya serta kesalahan manusia dalam mengeksploitasi dan mengolah sumberdaya alam yang tersedia, seperti longsor, banjir, kekeringan, intrusi air laut, kebakaran, pencemaran (air, tanah dan udara), sampah hujan asam, erosi dan kelaparan.${ }^{67} \mathrm{Hal}$ ini sesuai dengan aturan Islam, sebagaimana tercantum dalam Firman Allah SWT dalam Al-Qur'an yang artinya "Dan Kami telah menghamparkan bumi dan menjadikan padanya gunung-gunung dan Kami tumbuhkan padanya segala sesuatu menurut ukuran." 68

Oleh karenanya dapat kita menarik kesimpulan bahwa terjadinya bencana lingkungan yang kerap terjadi adalah tidak pandainya bahkan kecerobohan manusia didalam memanfaatkan alam sekitar secara berlebihan yang tidak memperhitungkan ukuran kemampuannya.

\footnotetext{
${ }^{64}$ Miftahul "Agama dan penyelamat lingkungan" http://lingkungan.muhammadiyah.or.id/in/artikel-agama-dan-penyelamatan-lingkungan--detail246.html (diakses tanggal 12 Februari 2018)

${ }^{65}$ Mujiyono Abdillah, "Islam dan Lingkungan Hidup, Justisia, Edisi 5, 1995: 45.

${ }^{66}$ Siswanto, Islam dan Pelestarian Lingkungan Hidup: Menggagas Pendidikan Islam Berwawasan Lingkungan Hidup, Karsa, 14 (2) Oktober 2008: 87.

${ }^{67}$ Andri Noor Ardiansyah, Peranan agama dalam pelestarian alam, http://pips.fitk.uinjkt.ac.id/?portfolio=peranan-agama-dalam-pelestarian-alam-lingkungan-pendekatanreligius-untuk-mengatasi-krisis-lingkungan (diakses 29 januari 2018).

${ }^{68}$ QS. Al Hijr : 19
} 
Qiro'ah| Jurnal Pendidikan Agama Islam

Vol. 11 No. 1 2021| https://ejurnal.iiq.ac.id/index.php/qiroah P-ISSN: 2085-0115 E-ISSN: 2656-3819

DOI: https://doi.org/10.33511/qiroah.v11n1.52-75
Diterima : 12 Mei 2021

Direvisi : 17 Mei2021

Disetujui : 03 Juni 2021

Diterbitkan : 12 Juni 2021

\section{PENUTUP}

Berdasarkan pembahasan diatas dapat disimpulkan bahwa seseorang yang belajar biologi akan mampu mendapatkan pemahaman ketauhidan (agama). Hal ini di tunjukkan dengan adanya nilai-nilai tauhid yang terkandung dalam matapelajaran biologi, diantaranya adalah tauhid rububiyah yakni meng-esa-kan Allah dengan perbuatan yaitu dengan cara memanfaatkan potensi yang ada pada manusia untuk memelihara dan melestarikan alam semesta sebagai bentuk ibadah kepada tuhan, kedua yaitu uluhiyah, ini ada pada bentuk tasbinya alam semesta berupa keteraturan dan keseimbangan alam semesta yang diciptakan Allah kepada setiap makhluknya, ketiga Asma' wa sifat, ini ada apa bentuk kasih kasih sayangnya Allah kepada setiap makhluk yang telah Dia cipatkan. Hal ini bisa dilihat dari materi-materi biologi seperti materi tentang metode ilmiah yang menganjurkan untuk memanfaatkan panca indra dalam menelaah ayat-ayat Allah, keanekaragaman hayati sebagai anugrah keindahan Allah, ekologi yang merupakan keteratuan dan keserasian ciptaan Allah dalam rangka merawat keseimbangan lingkungan (ekosistem).

\section{DAFTAR PUSTAKA}

Abdillah, Mujiyono. "Islam dan Lingkungan Hidup, Justisia, Edisi 5, 1995.

Abdussalam, Aam. "Pembelajaran Dalam Perspektif Al-Qur'an Al-Karim" Model-Model Pembelajaran Berbasis Nilai Islam (2014).

Al Attas, Syed Muhammad Naquib. Islam dan Sekularisme (Bandung : Institut Pemikiran Islam dan Pembangunan Insan, 2011).

Amin, Mohamad. Perkembangan Biologi dan Tantangan Pembelajarannya, Seminar Nasional $\begin{array}{llll}\text { Pendidikan dan } & \text { Saintek dalam }\end{array}$ https://publikasiilmiah.ums.ac.id/bitstream/handle/11617/7550/1\%20$\% 20$ Moh\%20Amin.pdf?sequence=1(Diakses Tanggal 15 November 2017)

Ardiansyah, Andri Noor. Peranan agama dalam pelestarian alam, http://pips.fitk.uinjkt.ac.id/?portfolio=peranan-agama-dalam-pelestarian-alam-lingkunganpendekatan-religius-untuk-mengatasi-krisis-lingkungan (diakses 29 januari 2018).

Arif, Mahmud. Pendidikan Islam Transformatif (Yogyakarta: LKIS, 2008).

Armstrong, Karen. Sejarah Tuhan (Bandung: Mizan, 2004).

Azra, Azyumardi. Pendidikan Islam : Tradisi Menuju Milenium Baru (Jakarta : Perebit Kalimah, 2001).

"Pengelimpokan Disiplin Ilmu Agama perspektif IAIN" dalam M. Amin Abdullah, dkk. edit. Antologi Studi Islam : Teori dan metodologi, (Yogyakarta : DIP PTA IAIN Sunan Kalijaga, 2000).

Bagir, Zainal Abidin. ed. Et. All, Integrasi Ilmu dan Agama : Interpretasi dan Aksi, (Bandung : Mizan, 2005).

Bakar, Osman. Tauhid dan Sains : Perspektif Islam tentang Agama \& Sains, judul asli Tawhid and Scince : Islamic Perspective on Religion and Science. (Bandung : Pustaka Hidayah, 200).

Barbour, Ian G. Juru Bicara Tuhan antara Sains dan Agama, (Bandung : Mizan, 2004).

Capra, Fritjof. Jaring-jaring Kehidupan : Visi Baru Epestimologi dan Kehidupan, (Yogyakarta : fajar pustaka baru, 2002).

, The Tao of Physics : Menyingkap Kesejajaran Fisika Modern Dan Mistisme Timur, (Yogyakarta : Jalasutra, 2000).

Darmana, Ayi. Internalisasi Nilai Tauhid dalam Pembelajaran Sains Vol. XVII No. 1 2012/1433.

73 | Qiro'ah Vo. 11 No.1 2021 
Qiro'ah| Jurnal Pendidikan Agama Islam

Vol. 11 No. 1 2021| https://ejurnal.iiq.ac.id/index.php/qiroah P-ISSN: 2085-0115 E-ISSN: 2656-3819

DOI: https://doi.org/10.33511/qiroah.v11n1.52-75
Diterima : 12 Mei 2021

Direvisi : 17 Mei2021

Disetujui : 03 Juni 2021

Diterbitkan : 12 Juni 2021

Fakhri, Jamal. "Sains dan Teknologi Dalam Al-Qur'an dan Implikasinya dalam Pembelajaran", Ta'dib, Vol. XV No. 01. Edisi, Juni 2010.

Farida, Umma. "Pemikiran Ismail Raji Al-Faruqi Tentang Tauhid, Sains, dan Seni” Fikrah, (Vol. 2, No. 2, Desember 2014).

Fua, Jumarddin La, Aktualisasi Pendidikan Islam dalam Pengelolaan Lingkungan Hidup Menuju Kesalehan Ekologis Jurnal, Al-Ta'dib Vol. 7 No. 1 Januari-Juni, 19-35, http:/ejournal.uinsuka.ac.id/tarbiyah/JPI/article/download/1194/1090 (diakses tanggal 12 Februari 2018

Griffin, David Ray. Tuhan dan Agama dalam Dunia Postmodern, (Bandung : 2005.).

Haq, Miftahul. "Agama dan lingkungan" http://lingkungan.muhammadiyah.or.id/in/artikel-agama-dan-penyelamatan-lingkungan-detail-246.html (diakses tanggal 12 Februari 2018)

Hidayat, Samsul. "Sacred Science vs. Secular Science: Carut Marut Hubungan Agama dan Sains", Kalam: Jurnal Studi Agama dan Pemikiran Islam Volume 8, Nomor 1, Juni 2014.

Karwadi, "Integrasi Paradigma Sains dan Agama dalam Pembelajaran Aqidah (Ketuhanan) (Telaah Tcoritis Dari Perspektif Kurikulum Integratif)" Jurnal Penelitian Agama, VOL. XVII, NO. 3September-Desember 2008.

Kertanegara, Mulyadi. Integrasi Ilmu : Sebuah Rekonstruksi Holistik, (Bandung, Arasy Mizan Pustaka, 2005).

Majid, Abdul. "Pendidikan Berbasis Ketuhanan : Mereposisi Pendidikan Agama Islam Untuk Mewujudkan Tujuan Pendidikan Nasional. Pidato pengukuhan jabatan guru besar ilmu pengkajian islanm pada jurusan mata kuliah fakultas pendidikan ilmu social Universitas Pendidikan Indonesia Rabu, 21 November 2017.

Majid, Nurcholish. Islam Agama Peradaban : Membangun Makna dan Relevansi Doktrin Islam Dalam sejarah, (Jakartat : Penerbit Paramadina, 1995).

Masruri, M. Hadi. dan Imron Rossidy, Filsafat Sains dalam Al qur'an : Melacak Kerangka Dasar Integrasi Ilmu dan Agama (Malang : UIN-Malang Press, 2007).

Monks, Bratton SP. "temples, and tress- the spirit of diversity." In Meffe GK and Carroll CR (eds), Principles of Conservation Biology. Sunderland, USA: Sinauer Associates Inc.; 1999).

Mustaqim, Abdul. "Etika Pemanfaatan Keakekaragaman Hayati Dalam Perspektif Al-Qur'an", Hermeneutik, Vol. 9, No.2, Desember 2015.

Nasr, Seyyed Hossein. A Young Muslim's Guide To The Modern World (Chicago : Kazi Publications. 2003).

Pengetahuan dan Kesucian, Terjemahan Suharsono dkk., Yogyakarta : Pustaka Pelajar dan CSIS, 1997

Nasution, Harun. Islam Rasional : gagasan dan pemikiran ( Bandung : mizan, 1995).

Negi, Chandra Singh. "Religion and biodiversity conservation: not a mere analogy" dalam https://doi.org/10.1080/17451590509618083 (diakses 2 februari 2018)

Othman, Zuraidah bt. Aizan Ali dan Mat Zin "Pendidikan Integratif Dalam Islam : Kesepaduan Iman, Ilmu dan Amal (Integrative Education In Islam : Unity Faith, Knowledge And Charity)

Peters, Ted. dan Gaymon Bennett, Menjembatani Sains dan Agama.(Gunung Mulia : Jakarta, 2006).

Prawihartono, Slamet Konsep dan Penerapan Biologi SMA/MA kelas Kelas X, Edisi Revisi 2016. (Jakarta : BumiAksara, 2016).

Russel, Betrand. Sejarah Filsafat Barat dan Kaitannya Dengan Kondisi Sosio-Politik Zaman Kuno Hingga Sekarang (Yogyakarta : Pustaka Pelajar, 2007).

Sholeh, Moh. Jufriyadi. "Pandangan dan Kritik yusuf al-Qardawi terhadap Pandangan Barat tentang Agama dan Ilmu Pengetahuan”. Marâji ‘: Jurnal Studi Keislaman Volume 2, Nomor 1, September 2015.

Siswanto, Islam dan Pelestarian Lingkungan Hidup: Menggagas Pendidikan Islam Berwawasan Lingkungan Hidup, Karsa, 14 (2) Oktober 2008. 
Qiro’ah| Jurnal Pendidikan Agama Islam

Vol. 11 No. 1 2021| https://ejurnal.iiq.ac.id/index.php/qiroah P-ISSN: 2085-0115 E-ISSN: 2656-3819

DOI: https://doi.org/10.33511/qiroah.v11n1.52-75
Diterima

Direvisi

: 12 Mei 2021

Disetujui

Diterbitkan
: 17 Mei2021

: 03 Juni 2021

: 12 Juni 2021

Sugiharto, Bambang. "Kata Pengantar" dalam David Ray Griffin, Tuhan dan Agama dalam Dunia Postmodern, (Bandung : 2005.).

Suprayogo, Imam. Pendidikan Berparadigma Al-Qur'an : Pergulatan Membangun Tradisi dan Aksi Pendidikan, (Malang: UIN Press Malang, 2004).

Teller, Edward. "Science and Morality": American Association for the Advancement of Science Vol. 280, No. 5367 May 22, 1998), 1200-1201 http://www.jstor.org/stable/2896053 (dikases 21 Januari 2015)

Umar, Atho'illah. "Teologi Posmodern: Menimbang Konsep Naturalisme-Teistik” Teosofi (Volume 2 Nomor 1 Juni 2012)

Wilber, Ken. A Theory of everything : Solusi Menyeluruh atas Masalah Masalah Kemanusiaan, (Bandung : Mizan, 2012). 